\title{
Genetic risk of Parkinson disease and progression:
}

\author{
An analysis of 13 longitudinal cohorts
}

Hirotaka Iwaki, MD, Cornelis Blauwendraat, PhD, Hampton L. Leonard, MS, Ganqiang Liu, PhD, Jodi Maple-Grødem, PhD, Jean-Christophe Corvol, MD, PhD, Lasse Pihlstrøm, MD, PhD,

Marlies van Nimwegen, PhD, Samantha J. Hutten, PhD, Khanh-Dung H. Nguyen, PhD, Jacqueline Rick, PhD, Shirley Eberly, MS, Faraz Faghri, MS, Peggy Auinger, MS, Kirsten M. Scott, MRCP, MPhil, Ruwani Wijeyekoon, MRCP, Vivianna M. Van Deerlin, MD, PhD, Dena G. Hernandez, PhD, Aaron G. Day-Williams, PhD, Alexis Brice, MD, Guido Alves, MD, PhD, Alastair J. Noyce, MRCP, PhD, Ole-Bjørn Tysnes, MD, PhD, Jonathan R. Evans, MRCP, PhD, David P. Breen, MRCP, PhD, Karol Estrada, PhD, Claire E. Wegel, MPH, Fabrice Danjou, MD, PhD, David K. Simon, MD, PhD, Bernard Ravina, MD, Mathias Toft, MD, PhD, Peter Heutink, PhD, Bastiaan R. Bloem, MD, PhD, Daniel Weintraub, MD, Roger A. Barker, MRCP, PhD, Caroline H. Williams-Gray, MRCP, PhD, Bart P. van de Warrenburg, MD, PhD, Jacobus J. Van Hilten, MD, PhD, Clemens R. Scherzer, MD, Andrew B. Singleton, PhD, and Mike A. Nalls, PhD

Neurol Genet 2019;5:e348. doi:10.1212/NXG.0000000000000348

\section{Abstract}

\section{Objective}

To determine if any association between previously identified alleles that confer risk for Parkinson disease and variables measuring disease progression.

\section{Methods}

We evaluated the association between 31 risk variants and variables measuring disease progression. A total of 23,423 visits by 4,307 patients of European ancestry from 13 longitudinal cohorts in Europe, North America, and Australia were analyzed.

\section{Results}

We confirmed the importance of GBA on phenotypes. GBA variants were associated with the development of daytime sleepiness (p.N370S: hazard ratio [HR] $3.28[1.69-6.34]$ ) and possible REM sleep behavior (p.T408M: odds ratio 6.48 [2.04-20.60]). We also replicated previously reported associations of $G B A$ variants with motor/cognitive declines. The other genotype-phenotype associations include an intergenic variant near LRRK2 and the faster development of motor symptom (Hoehn and Yahr scale 3.0 HR 1.33 [1.16-1.52] for the C allele of rs76904798) and an intronic variant in PMVK and the development of wearing-off effects (HR 1.66 [1.19-2.31] for the $C$ allele of rs114138760). Age at onset was associated with TMEM175 variant p.M393T (-0.72 [-1.21 to -0.23$]$ in years), the $\mathrm{C}$ allele of rs199347 (intronic region of GPNMB, 0.70 $[0.27-1.14]$ ), and G allele of rs1106180 (intronic region of CCDC62, $0.62[0.21-1.03]$ ).

\section{Conclusions}

This study provides evidence that alleles associated with Parkinson disease risk, in particular GBA variants, also contribute to the heterogeneity of multiple motor and nonmotor aspects. Accounting for genetic variability will be a useful factor in understanding disease course and in minimizing heterogeneity in clinical trials.

\begin{abstract}
From the Laboratory of Neurogenetics (H.I., C.B., H.L.L., F.F., D.G.H., A.B.S., M.A.N.), National Institute on Aging, National Institutes of Health, Bethesda; Data Tecnica International (H.I., M.A.N.), Glen Echo, MD; Precision Neurology Program (G.L., C.R.S.), Harvard Medical School, Brigham and Women's Hospital; Neurogenomics Laboratory (G.L., C.R.S.), Harvard Medical School, Brigham and Women's Hospital; Ann Romney Center for Neurologic Diseases (G.L., C.R.S.), Brigham and Women's Hospital, Boston, MA; The Norwegian Centre for Movement Disorders (J.M.-G., G.A.), Stavanger University Hospital; Department of Chemistry (J.M.-G., G.A.), Bioscience and Environmental Engineering, University of Stavanger, Norway: Assistance-Publique Hôpitaux de Paris (I.-C.C.), ICM, INSERM UMRS 1127, CNRS 7225, ICM, Department of Neurology and CIC Neurosciences, Pitié-Salpêtrière Hospital, Paris, France; Department of Neurology (L.P., M.T.), Oslo University Hospital, Norway; Department of Neurology (M.N., B.R.B., B.P.W.), Donders Institute for Brain, Cognition, and Behaviour, Radboud University Medical Centre, Nijmegen, The Netherlands; Michael J Fox Foundation (S.J.H.), New York; Translational Genome Sciences (K.-D.H.N, K.E.), Biogen, Cambridge, MA; Department of Neurology University of Pennsylvania (J.R.), Philadelphia, PA; Department of Biostatistics and Computational Biology (S.E.), University of Rochester, NY; Department of Computer Science (F.F.), University of Illinois Urbana-Champaign; Department of Neurology (P.A.), Center for Health + Technology, University of Rochester, NY; Department of Clinical Neurosciences (K.M.S., R.W.), University of Cambridge, John van Geest Centre for Brain Repair, UK; Department of Pathology and Laboratory Medicine (V.M.V.D.), Center for Neurodegenerative Disease Research, Parelman School of Medicine at the University of Pennsylvania, Philadelphia; Genetics and Pharmacogenomics (A.G.D.-W.), Merck Research Laboratory, Boston, MA; Statistical Genetics (A.G.D.-W.), Biogen, Cambridge, MA; Institut du cerveau et de la moelle épinière ICM (A.B., F.D.); Sorbonne Université SU (A.B.); INSERM $\mathrm{UMR}^{1127}$ (A.B.), Paris, France; Department of Neurology (G.A.), Stavanger University Hospital, Norway; Preventive Neurology Unit (A.J.N.), Wolfson Institute of Preventive Medicine, Queen Mary University of London; Department of Molecular Neuroscience (A.J.N.), UCL Institute of Neurology, London, UK; Department of Neurology (O.-B.T.), Haukeland University Hospital; University of Bergen (O.-B.T.), Bergen, Norway; Department of Neurology (I.R.E.), Nottingham University NHS Trust, UK; Centre for Clinical Brain Sciences (D.P.B.), University of Edinburgh; Anne Rowling Regenerative Neurology Clinic (D.P.B.), University of Edinburgh; Usher Institute of Population Health Sciences and Informatics (D.P.B.), University of Edinburgh, Scotland; Department of Medical and Molecular Genetics (C.E.W.), Indiana University, Indianapolis; Department of Neurology (D.K.S.), Beth Israel Deaconess Medical Center; Harvard Medical School (D.K.S.), Boston; Voyager Therapeutics (B.R.), Cambridge, MA; Department of Neurology (B.R.), University of Rochester School of Medicine, NY; Institute of Clinical Medicine (M.T.), University of Oslo, Norway; German Center for Neurodegenerative Diseases-Tubingen (P.H.); HIH Tuebingen (P.H.), Germany; Department of Psychiatry (D.W.), University of Pennsylvania School of Medicine; Department of Veterans Affairs (D.W.), Philadelphia, PA; and Department of Clinical Neurosciences (R.A.B., C.H.W.-G.), University of Cambridge, UK; Department of Neurology (J.J.V.H.), Leiden University Medical Center, The Netherlands.
\end{abstract}

Go to Neurology.org/NG for full disclosures. Funding information is provided at the end of the article.

The Article Processing Charge was funded by the NIH.

This is an open access article distributed under the terms of the Creative Commons Attribution-NonCommercial-NoDerivatives License 4.0 (CC BY-NC-ND), which permits downloading and sharing the work provided it is properly cited. The work cannot be changed in any way or used commercially without permission from the journal. 


\section{Glossary}

ESS = Epworth Sleepiness Scale; FDR = false discovery rate; GRS = genetic risk score; GWAS = genome-wide association study; HR = hazard ratio; HY = Hoehn and Yahr scale; MAF = minor allele frequency; MDS = Movement Disorder Society; MMSE = Mini-Mental State Examination; MoCA = Montreal Cognitive Assessment; MSQ = Mayo Sleep Questionnaire; NMS = nonmotor symptom; OR = odds ratio; PC = principal component; PDSS = Parkinson's Disease Sleep Scale; PPMI = Parkinson's Progression Markers Initiative; RBD = rapid eye movement sleep behavior disorder; RBDSQ = RBD Screening Questionnaire; RLS = restless legs syndrome; SEADL = Schwab and England Activities of Daily Living Scale; UPDRS = Unified Parkinson's Disease Rating Scale.

Parkinson disease is one of the most common neurodegenerative diseases, with an estimated lifetime risk as high as $1 \%-2 \%{ }^{1}$ Parkinson disease is traditionally characterized by motor features such as bradykinesia, rigidity, and tremor. However, in addition to these motor symptoms, patients with Parkinson disease also develop nonmotor symptoms (NMSs), which include depression, cognitive decline, sleep abnormalities, reduced olfaction, and autonomic dysfunction. $^{2}$ Collectively, the combined spectrum of motor and NMSs more accurately reflects the multisystem nature of the disease. Patients with Parkinson disease may present with various combinations of symptoms and show differences in the rates of progression. ${ }^{3}$ The application of modern molecular genetic approaches over the last decade has revealed a significant number of genetic risk loci for idiopathic Parkinson disease. ${ }^{4-7}$ However, in comparison with case-control genome-wide association study (GWAS), analyzing how genetic factors influence clinical presentation and progression requires longitudinal cohorts with much more detailed observations. Such data are sparse, and individual cohorts are often small in size and quite varied, posing a challenge both in sample size and heterogeneity.

In an attempt to address these issues, we collected data from 13 distinct longitudinal Parkinson disease cohorts with detailed clinical data, including assessment of disease progression. We sought to determine whether Parkinson disease genetic risk factors, either in the form of known GWAS variants or an aggregate genetic risk score (GRS), are associated with changes in clinical progression and the disease features.

\section{Methods}

\section{Study design and participants}

A total of 13 Parkinson disease cohorts from North America, Europe, and Australia participated in the study. Nine were prospective observational cohorts and the rest were from randomized clinical trials. The observational cohorts were Drug Interaction with Genes in Parkinson's Disease (DIGPD), Harvard Biomarkers Study (HBS), Oslo Parkinson's Disease study (partly including retrospective data), The Norwegian ParkWest study (ParkWest), Parkinson's Disease Biomarker Program (PDBP), Parkinsonism: Incidence and Cognitive and Non-motor heterogeneity In CambridgeShire (PICNICS), Parkinson's Progression Markers Initiative
(PPMI), Profiling Parkinson's disease study (ProPark), and the Morris K. Udall Centers for Parkinson's Research (Udall). The 4 cohorts from randomized clinical trials were Deprenyl and Tocopherol Antioxidative Therapy of Parkinsonism (DATATOP), NIH Exploratory Trials in Parkinson's Disease Large Simple Study 1, ParkFit study (ParkFit), and Parkinson Research Examination of CEP-1347 Trial with a subsequent prospective study (PreCEPT/PostCEPT). Information on these cohorts can be found in appendix e-1 (links.lww.com/ NXG/A169). Subsets of participants from the cohorts who provided DNA and were nonrelated participants with PD, diagnosed at age 18 years or later, and of European ancestry were included in the study. Participants' information and genetic samples were obtained under appropriate written consent and with local institutional and ethical approvals.

\section{Genotyping SNPs and calculation of GRS}

Oslo samples were genotyped on the Illumina Infinium OmniExpress array, DIGPD samples were genotyped by Illumina Multi-Ethnic Genotyping Array, and all other samples were genotyped on the NeuroX array. ${ }^{8}$ The quality control process of variant calling included GenTrain score $<0.7$, minor allele frequency (MAF) $>0.05$ (for sample quality control but not in our analysis of rare risk factors), and HardyWeinberg equilibrium test statistic $>10^{-6}$. Sample-specific quality control included a sample call rate of $>0.95$, confirmation of sex through genotyping, homozygosity quantified by $\mathrm{F}$ within $\pm 3 \mathrm{SD}$ from the population mean, European ancestry confirmed by principal-components analysis with 1000 Genomes data as the reference, and genetic relatedness of any 2 individuals $<0.125$. Detailed information regarding NeuroX and the quality control process has been described previously. ${ }^{9}$ In the present study, we investigated 31 single nucleotide polymorphisms (SNPs) previously shown to be significantly associated with Parkinson disease. ${ }^{10-12}$ In addition, we also calculated a GRS for each participant based on these variants. The scores were transformed into $Z$-scores within each cohort and treated as an exposure, with effect estimates based on $1 \mathrm{SD}$ change from the population mean. The list of 31 SNPs and the GRS calculation method are provided in table e-1 (links.lww.com/NXG/A170).

Furthermore, principal components (PCs) were created for each data set from genotypes using PLINK. For the PC calculation, variants were filtered for MAF $(>0.05)$, genotype missingness $(<0.05)$, and Hardy-Weinberg equilibrium $\left(p \geq 10^{-5}\right)$. 
The remaining variants were pruned (using a 50-kb window, with a 5 SNP shift per window and $r^{2}$ threshold of 0.5 ), and PCs were calculated using the pruned variants.

\section{Measurements}

The following clinical measurements and binomial outcomes were recorded longitudinally (table e-2 links.lww.com/NXG/A171): total and subscores of the Unified Parkinson's Disease Rating Scale (UPDRS) or the Movement Disorder Society revised UPDRS version (MDS-UPDRS); modified Hoehn and Yahr scales (HY); modified Schwab and England Activities of Daily Living Scale; and scores for the Mini-Mental State Examination (MMSE), The SCales for Outcomes in PArkinson's disease (SCOPA)-Cognition, and Montreal Cognitive Assessment (MoCA). Each was treated as a continuous outcome. For the UPDRS and MDS-UPDRS scores specifically, we took Z-scores of the total and subscores (except for part 4 at baseline) to compare the original and revised UPDRS versions. The conversion was applied to the scores for all subsequent visits. For UPDRS part 4, most participants had very low scores or 0 at baseline, so we normalized across all observations within each cohort. We also analyzed binomial outcomes. If we had access to the raw data, we used common cutoff values, which had been tested and reported specificity of $85 \%$ or more in patients' population. The binomial outcomes include existence of family history (1st-degree relative. 1st- and 2nd-degree relatives in HBS, PreCEPT, ProPark, and Udall), hyposmia (University of Pennsylvania Smell Identification Test $<21,{ }^{13}$ or answering "yes" to question 2 in the NMS questionnaire), cognitive impairment (SCOPA-Cognition $<23$, MMSE $<27$, or MoCA $<24,{ }^{14,15}$ or diagnosed with The Diagnostic and Statistical Manual of Mental Disorders -IV criteria for dementia), wearing off (UPDRS/MDS-UPDRS part 4 off time $>0$ or physician's diagnosis), dyskinesia (UPDRS/MDS-UPDRS part 4 dyskinesia time $>0$ or physician's diagnosis), depression (Beck Depression Inventory $>14$ [PICNICS used 9 instead of 14], Hamilton Depression Rating Scale $>9$, Geriatric Depression Scale [GRS] $>5,{ }^{16}$ or physician's diagnosis), constipation (MDSUPDRS part 1 item $11>0$, or answering "yes" to question 5 in the NMS questionnaire), excessive daytime sleepiness (Epworth sleepiness scale $>9,{ }^{17}$ insomnia [MDS-UPDRS part 1 , item $7>$ $0]$, rapid eye movement sleep behavior disorder [RBD]) (answered "yes" to question 1 on the Mayo Sleep Questionnaire $\left[\mathrm{MSQ},{ }^{18}\right.$ or RBD screening questionnaire [RBDSQ $\left.>5\right]$, ${ }^{19}$ restless legs syndrome [RLS]) (answered "yes" to MSQ question $3{ }^{20}$ or RLS diagnosis positive by RBDSQ), and the progression to $\mathrm{HY} \geq 3$ ( $\mathrm{HY} 3$, representing moderate to severe disease). The individual definitions of these binomial outcomes are summarized in table e-2 (links.lww.com/NXG/A171). Age, sex, years of education, age at motor symptom onset, and whether the patient was treated with levodopa or dopamine agonists at each visit were also recorded for adjustments.

\section{Statistical analysis}

\section{Cohort-level analysis}

We analyzed the association between exposures and outcomes using appropriate additive models. Covariates of interest were not available for all cohorts; therefore, the model specifications were slightly different between cohorts (detailed in table e-3, links.lww.com/NXG/A172). Briefly, the associations between an SNP/GRS and age at onset were analyzed by linear regression modeling adjusting for population stratification (PC1 and PC2). The association between family history of Parkinson disease and SNP/GRS was analyzed with a logistic regression model adjusting for PC1/2. For continuous variables, linear regression modeling adjusting for sex, education, $\mathrm{PC} 1 / 2$, age at onset, years from diagnosis, family history, and treatment status was applied. For those who had multiple observations, random intercept was added to adjust for repeated measurements of the same individual. For binomial outcomes, the logistic regression at baseline observation was applied using the same covariates as the continuous models. Those that were negative at baseline were further analyzed by a Cox regression with the same covariates but with treatment status as a time-varying covariate. Observations with missing variables were excluded from the analyses.

\section{Meta-analysis}

We applied inverse weighting (precision method) for each combination of outcome-predictor association and combined the estimates from the 13 different cohorts in a fixed effect model. Multiple test correction for SNPs was controlled with an overall false discovery rate (FDR) of 0.05 per outcome being considered significant. Similarly, multiple testing of outcomes for GRS was corrected with an FDR of 0.05, but across all traits. In addition, as a test of homogeneity, $I^{2}$ indices and forest plots were used for quantitative assessment. As a sensitivity analysis, we conducted up to 13 iterations of the meta-analyses for the 12 cohorts excluding each cohort per iteration. This analysis provides information regarding heterogeneity of the cohorts and how one specific cohort exclusion affects the results. The range of estimates and maximum $p$ values for the iterations were included. Finally, we conducted the 13-cohort meta-analysis in a random effects model with restricted maximum likelihood estimation using the same multiple testing correction.

All the above analyses were conducted with PLINK version 1.9, and $\mathrm{R}$ version 3.4.4 (64-bit). Statistical tests were all 2 sided.

\section{Data availability}

Qualified investigators can request raw data through the organizations' homepages (PDBP: pdbp.ninds.nih.gov/, PPMI: ppmi-info.org/) or collaboration.

\section{Results}

A total of 23,423 visits by 4,307 patients with a median followup period of 2.97 years (quartile range of [1.63-4.94] years) were eligible for the analysis. The baseline characteristics of the cohorts are shown in table 1 . The mean ages at onset varied from 54 to 69 years; the average disease durations at cohort entry ranged from less than 1 to 10 years, and the mean observation periods were between 1.2 and 6.8 years. All DATATOP, ParkWest, PPMI, and PreCEPT participants 
Table 1 Summary characteristics of 13 cohorts

\begin{tabular}{|c|c|c|c|c|c|c|c|c|c|c|c|c|c|}
\hline & DATATOP & DIGPD & HBS & $\begin{array}{l}\text { NET-PD } \\
\text { LS1 }\end{array}$ & Oslo & Parkfit & ParkWest & PDBP & PICNICS & PPMI & $\begin{array}{l}\text { PreCEPT/ } \\
\text { PostCEPT }\end{array}$ & ProPark & Udall \\
\hline Cohort size, $n$ & 440 & 311 & 580 & 406 & 317 & 335 & 150 & 422 & 120 & 357 & 321 & 296 & 252 \\
\hline $\begin{array}{l}\text { Follow-up } \\
\text { duration, y }\end{array}$ & $1.22(0.41)$ & $2.19(1.51)$ & $1.53(0.87)$ & $4.48(1.45)$ & $4.64(3.10)$ & $1.97(0.00)$ & $3.04(0.09)$ & $2.06(1.70)$ & $3.04(1.63)$ & $4.87(1.35)$ & $6.79(0.95)$ & $4.62(1.14)$ & $3.77(1.81)$ \\
\hline Female, $n(\%)$ & $146(33.2)$ & $121(38.9)$ & $201(34.7)$ & $148(36.5)$ & $107(33.8)$ & $110(32.8)$ & $57(38.0)$ & $174(41.2)$ & $43(35.8)$ & $121(33.9)$ & $106(33.0)$ & 105 (35.5) & $73(29.0)$ \\
\hline $\begin{array}{l}\text { Family history, } \\
\text { n (\%) }\end{array}$ & $86(20.9)$ & $69(22.3)$ & $148(25.5)$ & $59(14.5)$ & $43(14.0)$ & - & $17(11.3)$ & $54(12.8)$ & $19(15.8)$ & $48(13.5)$ & $93(29.2)$ & 76 (25.9) & $71(28.4)$ \\
\hline Age at onset, y & $58.65(9.17)$ & $59.41(9.80)$ & $62.16(10.46)$ & $60.64(9.45)$ & $54.33(10.06)$ & $60.79(8.65)$ & $67.27(9.26)$ & $58.51(10.28)$ & 68.94 (9.34) & $61.45(9.55)$ & $59.47(9.22)$ & $53.14(10.60)$ & $64.26(8.64)$ \\
\hline $\begin{array}{l}\text { Baseline from } \\
\text { diagnosis, y }\end{array}$ & $1.14(1.17)$ & $2.60(1.57)$ & $4.09(4.63)$ & $1.50(1.00)$ & $10.13(6.04)$ & $5.18(4.44)$ & $0.13(0.12)$ & $5.68(5.64)$ & $0.23(0.48)$ & $0.54(0.54)$ & $0.80(0.83)$ & $6.56(4.67)$ & $6.21(5.38)$ \\
\hline $\begin{array}{l}\text { Levodopa use, } \\
\text { n (\%) }\end{array}$ & $0(0.0)$ & $198(63.9)$ & 415 (71.6) & $207(51.2)$ & - & - & $0(0.0)$ & $255(60.4)$ & $36(30.0)$ & $0(0.0)$ & $0(0.0)$ & $202(68.2)$ & $215(85.3)$ \\
\hline $\begin{array}{l}\text { Dopamine } \\
\text { agonist use, } n \text { (\%) }\end{array}$ & $0(0.0)$ & $228(73.3)$ & $224(38.6)$ & $280(69.3)$ & - & - & $0(0.0)$ & $61(14.5)$ & $22(18.3)$ & $0(0.0)$ & $1(0.3)$ & $222(75.0)$ & $118(46.8)$ \\
\hline Modified HY & $1.61(0.53)$ & $1.75(0.55)$ & $2.14(0.64)$ & - & $2.19(0.64)$ & $2.08(0.33)$ & $1.86(0.58)$ & $2.04(0.69)$ & $1.64(0.67)$ & $1.55(0.50)$ & $1.75(0.48)$ & $2.51(0.79)$ & $2.29(0.68)$ \\
\hline UPDRS1 & - & $7.69(4.50)$ & $1.70(1.59)$ & $1.31(1.45)$ & - & - & $1.95(1.76)$ & $9.90(6.11)$ & - & $5.40(3.97)$ & $0.84(1.19)$ & - & $1.92(1.99)$ \\
\hline UPDRS2 & - & $7.72(4.66)$ & $9.21(5.23)$ & $7.29(3.86)$ & - & - & $8.19(4.22)$ & $11.14(8.01)$ & - & $5.80(4.11)$ & $6.11(3.20)$ & - & $10.74(7.13)$ \\
\hline UPDRS3 & - & $20.37(10.23)$ & $19.30(9.58)$ & $17.77(8.32)$ & $15.42(10.30)$ & - & $22.09(9.77)$ & $23.64(13.08)$ & - & $20.88(9.00)$ & $18.69(7.65)$ & - & $22.92(11.09)$ \\
\hline UPDRS4 & - & $0.66(2.56)$ & $2.25(2.05)$ & $1.34(1.49)$ & - & - & $0.57(1.14)$ & $2.20(3.17)$ & - & - & - & - & $2.02(2.75)$ \\
\hline MDS_UPDRS total & - & $36.43(16.02)$ & - & - & - & - & - & $46.88(24.04)$ & $47.27(17.97)$ & - & - & - & - \\
\hline UPDRS total & $24.68(11.56)$ & - & $32.33(14.28)$ & $27.67(11.62)$ & - & $32.11(10.10)$ & 32.79 (13.91) & - & - & - & $25.39(10.10)$ & - & $32.64(18.28)$ \\
\hline MMSE & $28.99(1.35)$ & $28.38(1.73)$ & $28.35(2.17)$ & - & - & $28.09(1.61)$ & $27.88(2.27)$ & - & $28.71(1.43)$ & - & $29.29(1.07)$ & $27.05(2.50)$ & $26.83(3.50)$ \\
\hline MoCA & - & - & - & - & - & - & - & $25.44(3.40)$ & - & $27.17(2.23)$ & - & - & $24.37(3.63)$ \\
\hline SEADL & $91.55(6.49)$ & $80.55(29.02)$ & - & $91.59(6.06)$ & - & - & $89.40(7.35)$ & $85.11(13.10)$ & - & $93.18(5.91)$ & $92.77(5.26)$ & - & $80.53(17.56)$ \\
\hline Hyposmia, n (\%) & - & $89(28.9)$ & - & - & - & - & $54(36.0)$ & $276(65.4)$ & - & $164(45.9)$ & - & $173(63.8)$ & $69(67.0)$ \\
\hline $\begin{array}{l}\text { Cognitive } \\
\text { impairment, } n(\%)\end{array}$ & $26(5.9)$ & $3(1.0)$ & $74(13.0)$ & $29(7.1)$ & - & $55(16.4)$ & $27(18.0)$ & $96(22.7)$ & $11(9.2)$ & $28(7.8)$ & $3(0.9)$ & $77(27.0)$ & $29(11.5)$ \\
\hline $\begin{array}{l}\text { Motor } \\
\text { fluctuation, } \mathrm{n}(\%)\end{array}$ & - & $40(12.9)$ & $228(39.9)$ & $103(25.4)$ & - & - & $4(2.7)$ & $129(48.1)$ & $1(0.8)$ & - & - & $94(32.4)$ & 75 (35.4) \\
\hline Dyskinesia, n (\%) & $4(0.9)$ & $13(4.2)$ & $207(36.2)$ & $5(1.2)$ & - & - & $2(1.3)$ & $196(46.4)$ & $0(0.0)$ & - & - & $81(27.6)$ & $44(22.8)$ \\
\hline
\end{tabular}


were dopaminergic therapy naive at baseline; patients in the other cohorts were not. In the primary analysis of 13 cohorts, 17 associations were identified as significant after FDR correction (table 2, and more information in table e-4, links.lww. com/NXG/A173). Overwhelmingly, 10 were associated with GBA variants. In particular, GBA p.E365K (rs2230288) was associated with 2.37- (1.53-3.66) (95\% CI) fold higher odds of having cognitive impairment at baseline $\left(p=1.09 \times 10^{-4}\right)$ and 2.78- (1.88-4.11) fold higher hazard ratio (HR) of developing cognitive impairment during follow-up among those who were negative for cognitive impairment at baseline ( $p=$ $\left.2.97 \times 10^{-7}\right)$. This SNP was also associated with a higher mean on the HY at $0.10(0.04-0.16)\left(p=1.53 \times 10^{-3}\right)$, but the test of homogeneity was rejected $\left(p=0.017, I^{2}=48.9 \%\right)$. In addition, it was associated with the development of an RBD among those who did not have the disorder at baseline. Other GBA mutations, p.N370S (rs767763715) and p.T408M (rs75548401), were both associated with a higher HR of reaching HY3 (4.59 $[2.60-8.10]$ for $\mathrm{p} . \mathrm{N} 370 \mathrm{~S}\left[p=1.58 \times 10^{-7}\right]$ and $1.93[1.34-2.78]$ for p.T408M $\left.\left[p=4.40 \times 10^{-4}\right]\right)$. GBA p.N370N was also associated with a higher risk of developing wearing-off, dyskinesia, and daytime sleepiness. p.T408M was associated with a 6.48 (2.04-20.60) times higher odds ratio (OR) of having an RBD symptom at baseline $\left(p=1.53 \times 10^{-3}\right)$.

Two LRRK2 variants in our 31 SNPs of interest were significantly associated with outcomes. LRRK2 p.G2019S (rs34637584) was associated with higher odds of having a family history of Parkinson disease (OR 3.54 [1.72-7.29], $p=6.06 \times$ $10^{-4}$ ), and the $\mathrm{T}$ allele of rs 76904798 (intergenic at the $5^{\prime}$ end of LRRK2) was associated with a higher $\mathrm{HR}$ of reaching $\mathrm{HY} 3$ ( $\mathrm{HR}$ $1.33[1.16-1.52]$ for the $\mathrm{T}$ allele, $p=5.27 \times 10^{-5}$ ).

Age at onset was inversely associated with the $Z$ value of the GRS $\left(-0.60[-0.89\right.$ to -0.31$]$ years per $\left.+1 \mathrm{SD}, p=5.33 \times 10^{-5}\right)$. Moreover, it was associated with rs34311866 (TMEM175 p.M393T), the C allele of rs 199347 (intronic region of GPNMB), and the $\mathrm{G}$ allele of rs1106180 (intronic region of CCDC62).

The majority (14/17) of associations showed good accord across cohorts $\left(\mathrm{I}^{2}<50 \%\right)$, and the forest plots (figures 1-3) also illustrate this qualitatively. Furthermore, up to 13 iterations of the leave-one-out analysis assessed 15 associations of which outcomes were measured in more than 2 cohorts and showed a small range of betas. The maximum $p$ value of 13 iterations was less than 0.05 for all associations except for rs 114138769 (intron of PMVK) and rs76763715 (GBA p.N370S) for wearing-off. A meta-analysis with a random effect model also detected 9 associations after the same FDR correction, although the model is more conservative than a fixed model.

\section{Discussion}

We conducted a meta-analysis with 13 longitudinal patient cohorts and identified multiple associations between genotypes and clinical phenotypic characteristics, including 
Table 2 Meta-analysis for 13 cohorts and the results of sensitivity analysis

\begin{tabular}{|c|c|c|c|c|c|c|c|c|c|c|c|c|}
\hline \multirow[b]{2}{*}{ Outcome } & \multirow[b]{2}{*}{ rsNo } & \multirow{2}{*}{$\begin{array}{l}\text { Known gene } \\
\text { or nearest } \\
\text { gene }\end{array}$} & \multirow[b]{2}{*}{$\begin{array}{l}\text { No. of } \\
\text { cohorts }\end{array}$} & \multirow[b]{2}{*}{$\begin{array}{l}\text { Scale of the } \\
\text { effect }\end{array}$} & \multicolumn{2}{|l|}{ Fixed effect model } & \multirow[b]{2}{*}{$\begin{array}{l}\text { Test of } \\
\text { homogeneity }\end{array}$} & \multirow[b]{2}{*}{$I^{2}(\%)$} & \multicolumn{2}{|l|}{ Leave-one-out analysis } & \multicolumn{2}{|l|}{ Random effect model } \\
\hline & & & & & Estimate $(95 \% \mathrm{Cl})$ & $p$ & & & $\begin{array}{l}\text { Estimate (Min to } \\
\text { Max) }\end{array}$ & $\operatorname{Max} p$ & Estimate $(95 \% \mathrm{Cl})$ & $p$ \\
\hline Wearing-off & rs114138760 & intron_PMVK & 9 & Multiplicative (HR) & 1.66 (1.19 to 2.31$)$ & $2.62 \mathrm{E}-03$ & 0.322 & 12.58 & $1.66(1.44$ to 1.81$)$ & $6.22 \mathrm{E}-02$ & 1.65 (1.14 to 2.38$)$ & 7.39E-03 \\
\hline Dyskinesia & rs76763715 & GBA:N370S & 8 & Multiplicative (HR) & 3.01 (1.81 to 5.01$)$ & $2.17 \mathrm{E}-05$ & 0.011 & 60.53 & 3.00 (1.98 to 4.05$)$ & $2.26 \mathrm{E}-02$ & 2.49 (1.06 to 5.86$)$ & $3.73 \mathrm{E}-02$ \\
\hline$H Y \geq 3.0$ & rs76763715 & GBA:N370S & 6 & Multiplicative (HR) & 4.59 (2.60 to 8.10$)$ & $1.58 \mathrm{E}-07$ & 0.654 & 0.00 & 4.59 (4.02 to 5.41$)$ & $2.00 \mathrm{E}-05$ & 4.59 (2.60 to 8.10$)$ & $1.58 \mathrm{E}-07^{\mathrm{a}}$ \\
\hline Wearing-off & rs76763715 & GBA:N370S & 6 & Multiplicative (HR) & $2.03(1.28$ to 3.21$)$ & $2.56 \mathrm{E}-03$ & 0.021 & 62.70 & $2.02(1.61$ to 2.65$)$ & $8.67 \mathrm{E}-02$ & 1.92 (0.85 to 4.33$)$ & $1.14 \mathrm{E}-01$ \\
\hline $\begin{array}{l}\text { Daytime } \\
\text { sleepiness }\end{array}$ & rs76763715 & GBA:N370S & 6 & Multiplicative (HR) & 3.28 (1.69 to 6.34$)$ & 4.24E-04 & 0.467 & 0.00 & 3.30 (2.85 to 4.38$)$ & $3.75 \mathrm{E}-03$ & 3.28 (1.69 to 6.34$)$ & $4.24 \mathrm{E}-04^{\mathrm{a}}$ \\
\hline$H Y \geq 3.0$ & rs75548401 & GBA:T408M & 8 & Multiplicative (HR) & 1.93 (1.34 to 2.78$)$ & 4.40E-04 & 0.208 & 32.43 & $1.93(1.70$ to 2.41$)$ & $1.08 \mathrm{E}-02$ & 1.96 (1.22 to 3.14$)$ & $5.22 \mathrm{E}-03$ \\
\hline pRBD (baseline) & rs75548401 & GBA:T408M & 2 & Multiplicative (OR) & 6.48 (2.04 to 20.60$)$ & $1.53 \mathrm{E}-03$ & 0.118 & 59.06 & - & - & 6.25 (1.02 to 38.20$)$ & $4.72 \mathrm{E}-02$ \\
\hline HY & rs2230288 & GBA:E365K & 12 & Continuous & 0.10 (0.04 to 0.16$)$ & $1.53 \mathrm{E}-03$ & 0.017 & 48.90 & $0.10(0.08$ to 0.11$)$ & $1.02 \mathrm{E}-02$ & 0.11 (0.02 to 0.21$)$ & $1.88 \mathrm{E}-02$ \\
\hline $\begin{array}{l}\text { Cognitive } \\
\text { impairment } \\
\text { (baseline) }\end{array}$ & rs2230288 & GBA:E365K & 8 & Multiplicative (OR) & 2.37 (1.53 to 3.66$)$ & 1.09E-04 & 0.794 & 0.00 & 2.37 (2.20 to 2.59 ) & $8.57 \mathrm{E}-04$ & 2.37 (1.53 to 3.66$)$ & $1.09 \mathrm{E}-04^{\mathrm{a}}$ \\
\hline $\begin{array}{l}\text { Cognitive } \\
\text { impairment }\end{array}$ & rs2230288 & GBA:E365K & 9 & Multiplicative (HR) & 2.78 (1.88 to 4.11$)$ & 2.97E-07 & 0.555 & 0.00 & 2.78 (2.41 to 2.98 ) & $5.08 \mathrm{E}-05$ & 2.78 (1.88 to 4.11$)$ & $2.97 \mathrm{E}-07^{\mathrm{a}}$ \\
\hline pRBD & rs2230288 & GBA:E365K & 2 & Multiplicative (HR) & 2.57 (1.43 to 4.63$)$ & 1.69E-03 & 0.665 & 0.00 & - & - & 2.57 (1.43 to 4.63 ) & $1.69 \mathrm{E}-03^{\mathrm{a}}$ \\
\hline Age at onset & rs34311866 & $\begin{array}{l}\text { TMEM175: } \\
\text { M393T }\end{array}$ & 13 & Continuous & $-0.72(-1.21$ to -0.23$)$ & 3.87E-03 & 0.515 & 0.00 & $-0.72(-0.83$ to -0.58$)$ & $2.83 \mathrm{E}-02$ & $-0.72(-1.21$ to -0.23$)$ & \\
\hline Age at onset & rs199347 & intron_GPNMB & 12 & Continuous & $0.70(0.27$ to 1.14$)$ & $1.42 \mathrm{E}-03$ & 0.824 & 0.00 & 0.70 (0.60 to 0.77$)$ & $1.12 \mathrm{E}-02$ & 0.70 (0.27 to 1.14$)$ & $1.42 \mathrm{E}-03^{\mathrm{a}}$ \\
\hline$H Y \geq 3.0$ & rs76904798 & 5_LRRK2 & 13 & Multiplicative (HR) & 1.33 (1.16 to 1.52$)$ & $5.27 \mathrm{E}-05$ & 0.049 & 43.15 & 1.33 (1.26 to 1.43 ) & $1.64 \mathrm{E}-03$ & 1.34 (1.11 to 1.63$)$ & $2.80 \mathrm{E}-03^{\mathrm{a}}$ \\
\hline Family history & rs34637584 & LRRK2:G2019S & 8 & Multiplicative (OR) & 3.54 (1.72 to 7.29$)$ & $6.06 \mathrm{E}-04$ & 0.856 & 0.00 & 3.53 (2.78 to 3.98 ) & $1.66 \mathrm{E}-02$ & 3.54 (1.72 to 7.29$)$ & $6.06 \mathrm{E}-04^{\mathrm{a}}$ \\
\hline Age at onset & rs11060180 & intron_CCDC62 & 13 & Continuous & 0.62 (0.21 to 1.03 ) & $3.32 \mathrm{E}-03$ & 0.054 & 42.60 & 0.62 (0.49 to 0.75 ) & $2.74 \mathrm{E}-02$ & 0.55 (-0.00 to 1.11$)$ & $5.14 \mathrm{E}-02$ \\
\hline Age at onset & GRS & & 13 & Continuous & $-0.60(-0.89,-0.31)$ & 5.33E-05 & 0.749 & 0.00 & $-0.60(-0.65,-0.52)$ & $9.02 \mathrm{E}-04$ & $-0.60(-0.89,-0.31)$ & $5.33 \mathrm{E}-05^{\mathrm{a}}$ \\
\hline
\end{tabular}

Abbreviations: FDR = false discovery rate; GRS = genetic risk score; $\mathrm{HR}$ = hazard ratio; $\mathrm{HY}=$ Hoehn and Yahr scale; $\mathrm{OR}=$ odds ratio; $\mathrm{PRBD}$ = possible REM sleep behavior disorder.

PRBD was only available in 2 cohorts and a leave-one-out analysis was not conducted for this outcome.

a Significant after FDR adjustment in a random effect model. 
Figure 1 Forest plots for GBA (p.N370S and p.T408M) variants and symptoms of Parkinson disease
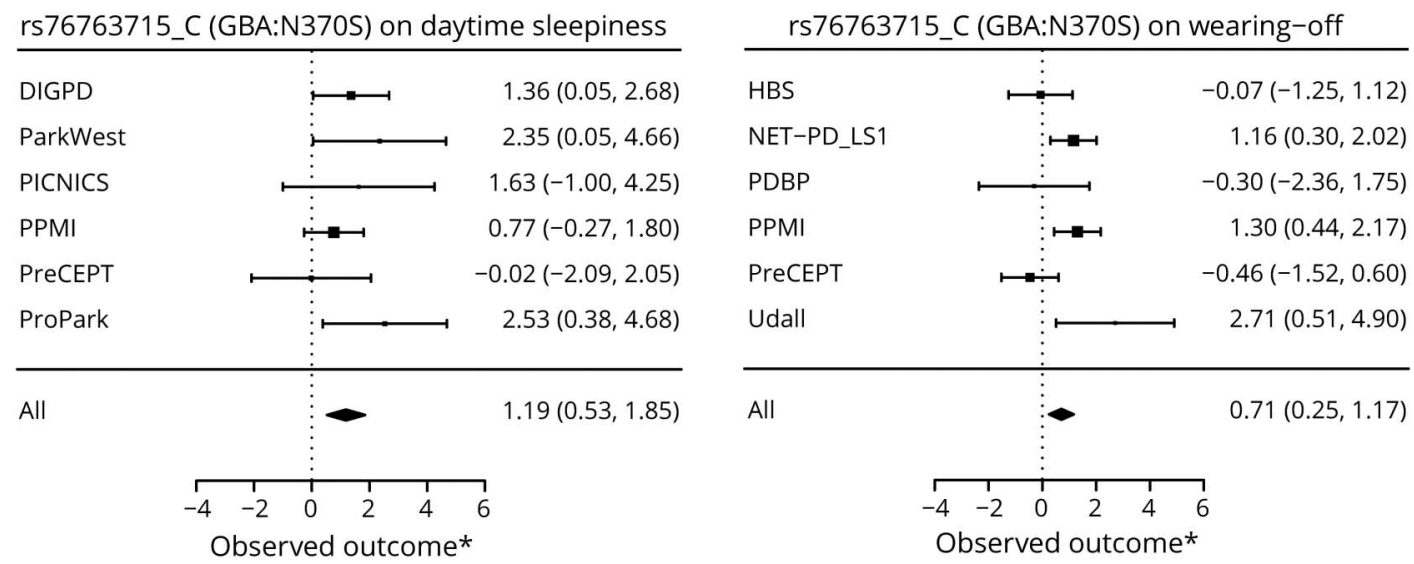

rs76763715_C(GBA:N370S) on HY $\geq 3$

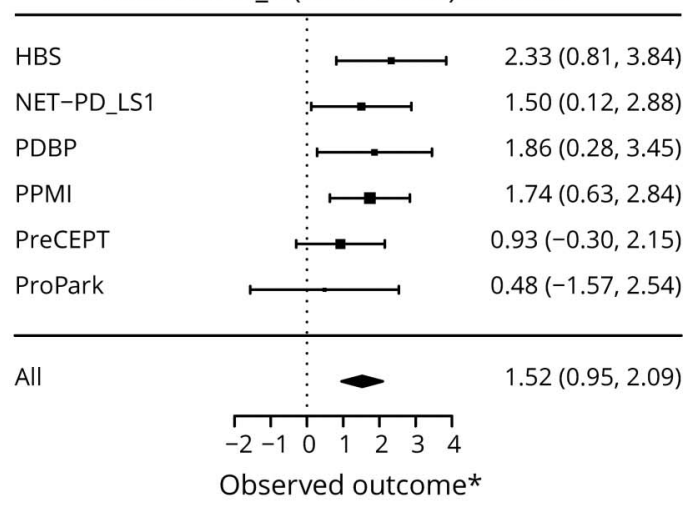

rs76763715_C (GBA:N370S) on dyskinesia

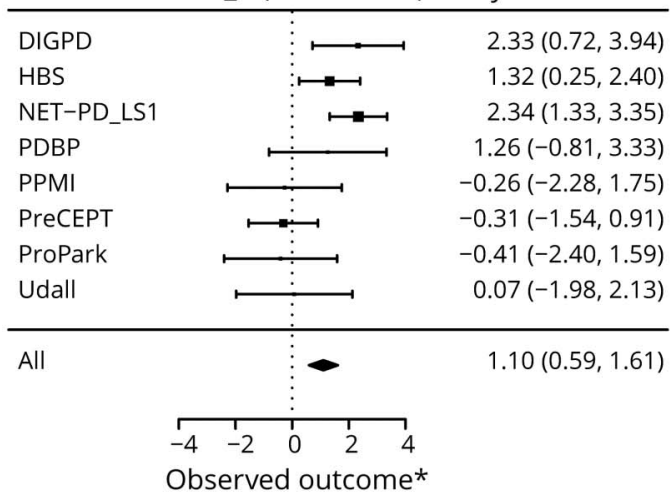

rs75548401_A (GBA:T408M) on REM

rs75548401_A (GBA:T408M) on HY $\geq 3$

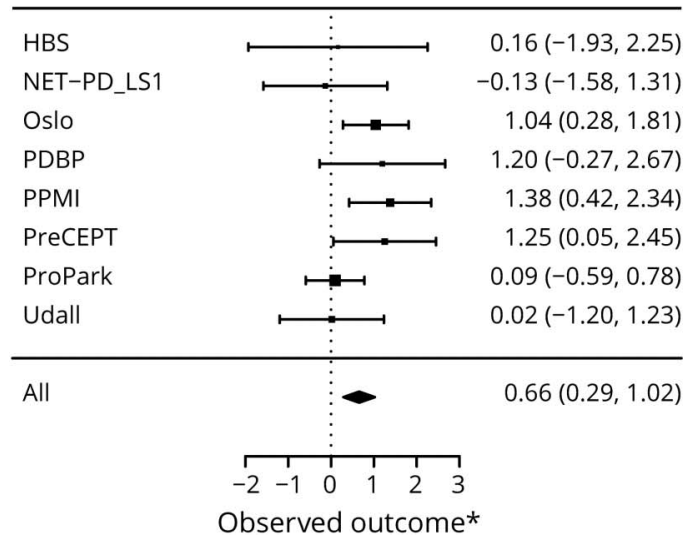

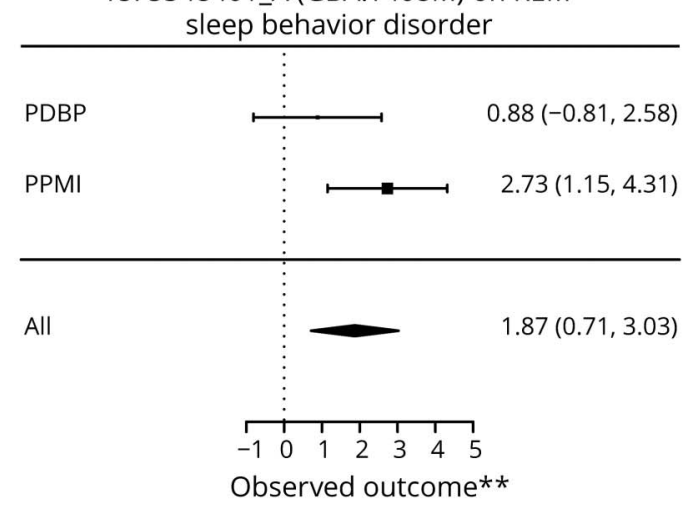

DATATOP = Deprenyl and Tocopherol Antioxidative Therapy of Parkinsonism; DIGPD = Drug Interaction with Genes in Parkinson's Disease; HBS = Harvard Biomarkers Study; NET-PD LS1 = NIH Exploratory Trials in Parkinson's Disease Large Simple Study 1; Oslo = Oslo PD study: ParkFit = ParkFit study; ParkWest = the Norwegian ParkWest study; PDBP = Parkinson's Disease Biomarker Program; PICNICS = Parkinsonism: Incidence and Cognitive and Non-motor heterogeneity In CambridgeShire; PPMI = Parkinson's Progression Markers Initiative; PreCEPT/PostCEPT = Parkinson Research Examination of CEP-1347 Trial with a subsequent prospective study; ProPark = Profiling Parkinson's Disease study; Udall = Morris K. Udall Centers for Parkinson's Research. * Indicates Beta in a Cox model; ** indicates Beta in a logistic model at baseline.

progression rates. Among these, GBA coding variants showed clear associations with the rate of cognitive decline (binomial outcome or UPDRS part 1 score) and motor symptom progression (HY, HY3), consistent with previous studies. ${ }^{12,21-25}$
In addition, we found associations between $G B A$ variants and $\mathrm{RBD}$ and daytime sleepiness. A previous cross-sectional study with 120 Ashkenazi-Jewish patients reported a higher frequency of RBDSQ-detected RBD symptoms in GBA variant carriers. ${ }^{26}$ 
Figure 2 Forest plots for GBA (p.E365K) variants and symptoms of Parkinson disease

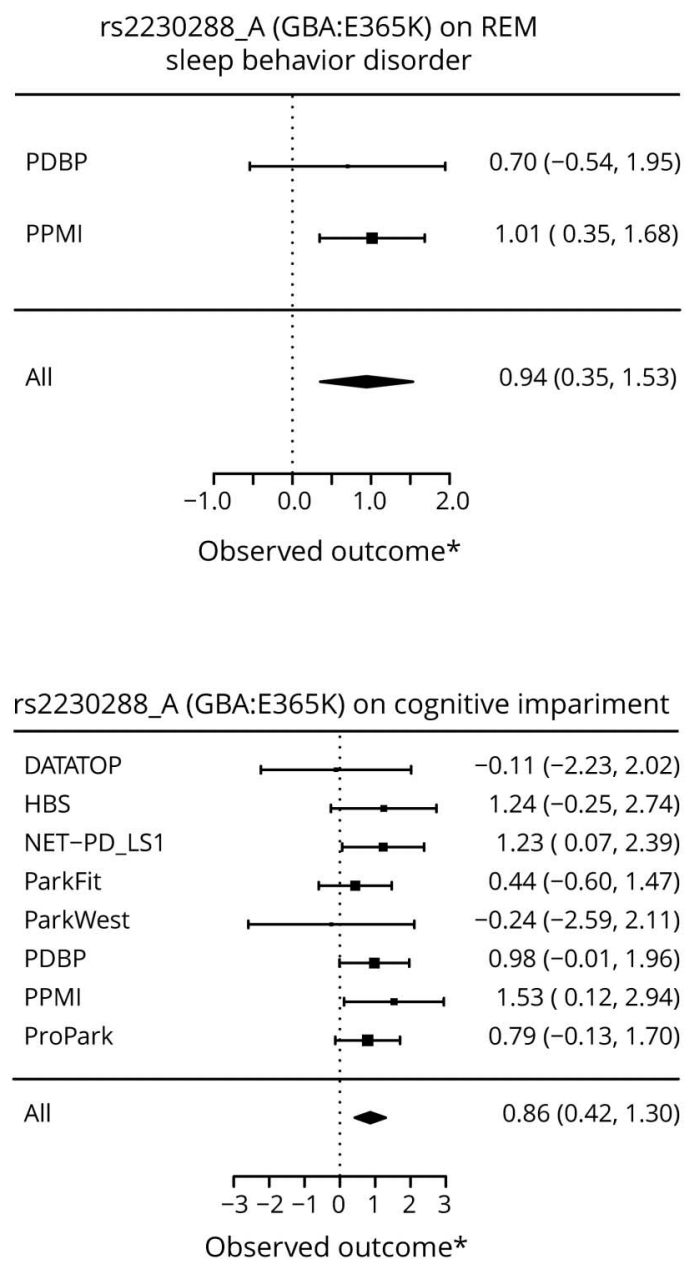

rs2230288_A (GBA:E365K) on cognitive impariment

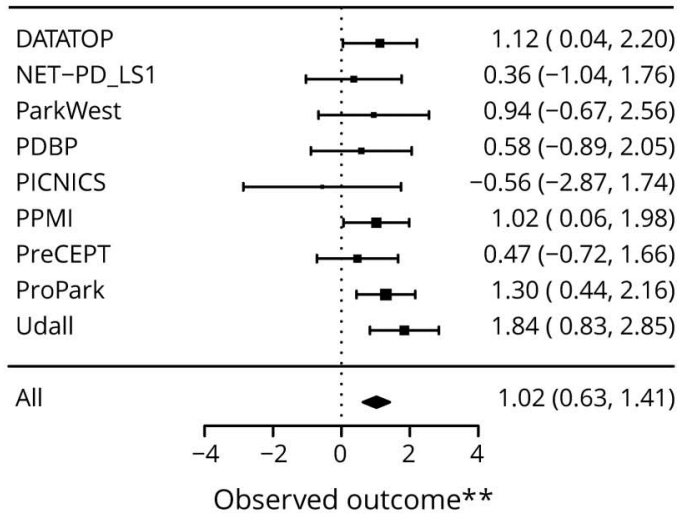

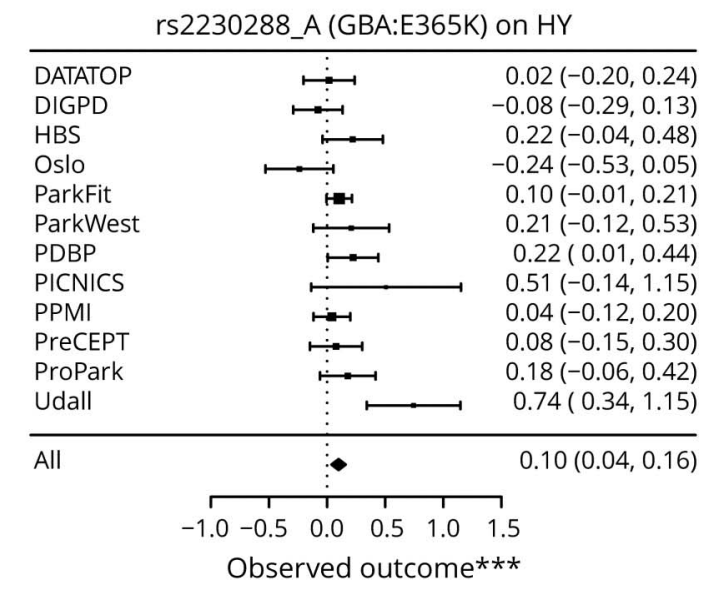

DATATOP $=$ Deprenyl and Tocopherol Antioxidative Therapy of Parkinsonism; DIGPD = Drug Interaction with Genes in Parkinson's Disease; HBS $=$ Harvard Biomarkers Study; NET-PD_LS1 = NIH Exploratory Trials in Parkinson's Disease Large Simple Study 1; Oslo = Oslo PD study; ParkFit = ParkFit study; ParkWest = the Norwegian ParkWest study; PDBP = Parkinson's Disease Biomarker Program; PICNICS = Parkinsonism: Incidence and Cognitive and Non-motor heterogeneity In CambridgeShire; PPMI = Parkinson's Progression Markers Initiative; PreCEPT/PostCEPT = Parkinson Research Examination of CEP-1347 Trial with a subsequent prospective study; ProPark = Profiling Parkinson's Disease study; Udall = Morris K. Udall Centers for Parkinson's Research. * Indicates Beta in a Cox model; ** indicates Beta in a logistic model at baseline; *** indicates Beta in a linear mixed model.

Our finding suggests that $G B A$ is associated not only with baseline clinical presentation but also with disease progression.

An association between GBA and daytime sleepiness has been rarely documented. One study reported an association between sleep problems (as assessed by the Parkinson's Disease Sleep Scale) and GBA. ${ }^{27}$ However, this scale is a combined measure of daytime sleepiness and other aspects of sleep problems.

Finally, a GBA variant (p.N370S) was also associated with treatment-related complications of wearing-off and dyskinesia. Two studies have reported the association of $G B A$ variants with these complications, with 1 positive and 1 negative result. $^{28,29}$ The negative result may be due to insufficient power with only 19 patients with GBA mutations.

Overall, our study provides a distinct clinical profile of patients with GBA variants compared with those without. We note that with 63 carriers for p.N370S, 166 for p.T408M, and 217 for p.E365K, we have a reasonable power, but the number is yet not enough. And this may affect the results in seemingly different magnitudes of associations and the association for different traits per variants (e.g., motor complications with p.N370S and cognitive impairment with p.E365K). Another possible explanation is that although the effects are associated with the same gene, the biological activity or molecular mechanism could be different. Such an example has already been reported for LRRK2 p.G2019S and p.G2385R. ${ }^{30}$

Aside from GBA variants, the associations between close intergenic ( $5^{\prime}$ _end) variant of LRRK2, rs76904798, and the faster development of motor symptom, and the intronic region variant of PMVK, rs114138760, and the development of wearing-off, were significant. This variant is $4.3 \mathrm{~kb}$ upstream from the $5^{\prime}$ end of $L R R K 2$ and reported to be associated with $L R R K 2$ gene expression changes in recent blood cis- 


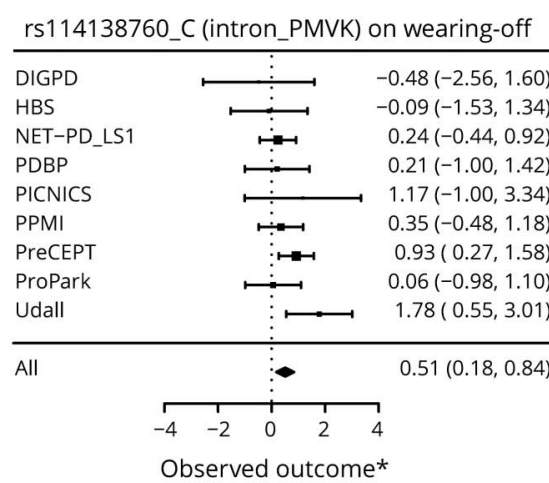

rs76904798_T (5_LRRK2) on $\mathrm{HY} \geq 3$

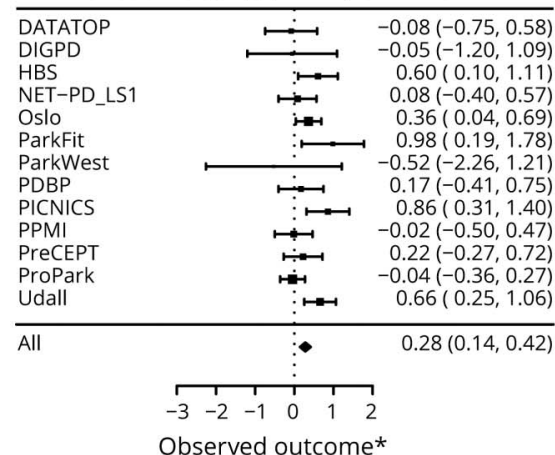

Observed outcome*

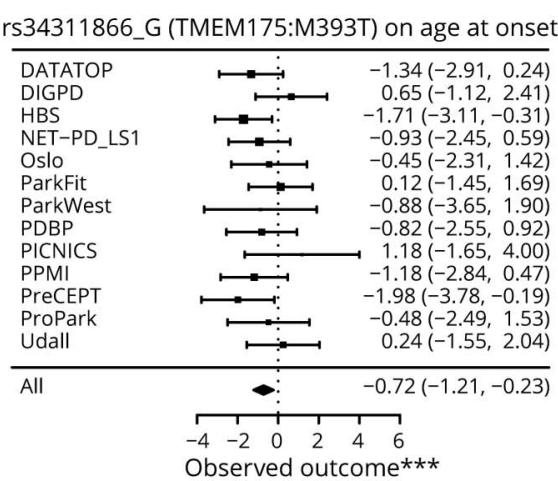

rs34637584_A (LRRK2:G2019S) on family history

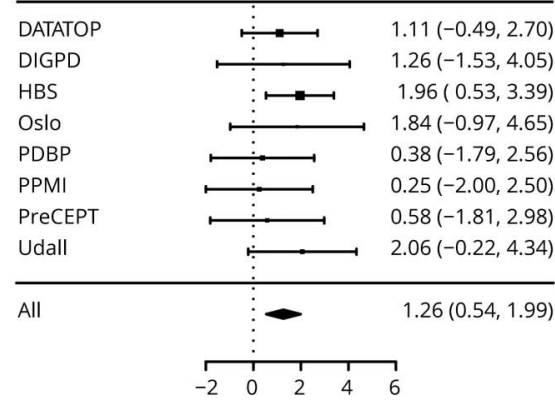

Observed outcome**
rs199347_C (intron_GPNMB) on age at onset

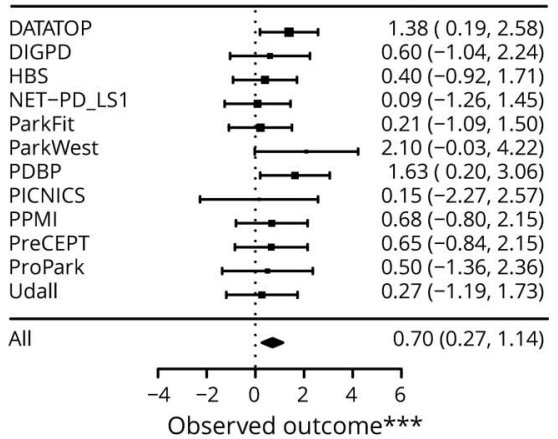

rs11060180_G (intron_CCDC62) on age at onset

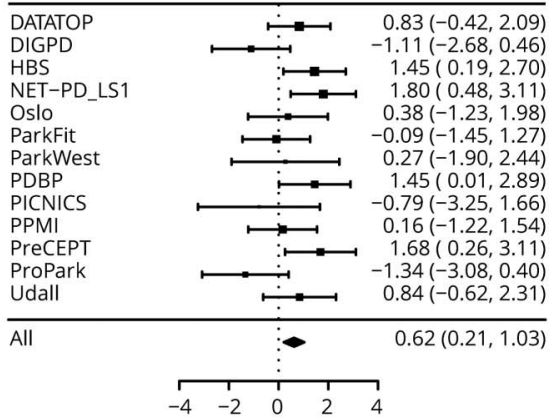

Observed outcome ${ }^{\star \star \star}$

grsZ on age at onset

\begin{tabular}{|c|c|c|}
\hline $\begin{array}{l}\text { DATATOP } \\
\text { DIGPD } \\
\text { HBS } \\
\text { NET-PD_LS1 } \\
\text { Oslo } \\
\text { ParkFit } \\
\text { ParkWest } \\
\text { PDBP } \\
\text { PICNICS } \\
\text { PPMI } \\
\text { PreCEPT } \\
\text { ProPark } \\
\text { Udall }\end{array}$ & (1) & $\begin{array}{r}-1.20(-2.07,-0.34) \\
-0.66(-1.78,0.47) \\
-0.85(-1.74,0.05) \\
-0.17(-1.10,0.76) \\
-0.49(-1.60,0.62) \\
-0.52(-1.46,0.42) \\
-0.34(-1.87,1.19) \\
-0.71(-1.70,0.27) \\
0.45(-1.24,2.15) \\
-1.36(-2.34,-0.38) \\
-0.21(-1.22,0.80) \\
-0.46(-1.69,0.77) \\
-0.10(-1.17,0.96)\end{array}$ \\
\hline All & $<:$ & $-0.60(-0.89,-0.31)$ \\
\hline
\end{tabular}

DATATOP = Deprenyl and Tocopherol Antioxidative Therapy of Parkinsonism; DIGPD = Drug Interaction with Genes in Parkinson's Disease; HBS = Harvard Biomarkers Study; NET-PD_LS1 = NIH Exploratory Trials in Parkinson's Disease Large Simple Study 1; Oslo = oslo PD study; ParkFit = ParkFit study; ParkWest = the Norwegian ParkWest study; PDBP = Parkinson's Disease Biomarker Program; PICNICS = Parkinsonism: Incidence and Cognitive and Non-motor heterogeneity In CambridgeShire; PPMI = Parkinson's Progression Markers Initiative; PreCEPT/PostCEPT = Parkinson Research Examination of CEP-1347 Trial with a subsequent prospective study; ProPark = Profiling Parkinson's Disease study; Udall = Morris K. Udall Centers for Parkinson's Research. * Indicates Beta in a Cox model; ** indicates Beta in a logistic model at baseline; *** indicates Beta in a linear mixed model.

expression quantitative trait loci (eQTL) study from the eQTLGen Consortium. ${ }^{31}$ In contrast, we did not find an association between rs34637584, LRRK2 coding mutation (p.G2019S) and motor progression. The p.G2019 variant is a rare variant (MAF $0.5 \%$ in our study), and our sample size was not adequate barring an extremely large effect size. The intronic region variant of PMVK, rs114138760, and the development of wearing-off was another finding. The biological effect of PMVK on PD has not been reported, but the variant is also located at close proximity of the GBA-SYT11 locus, so it is possible that its association was through a similar mechanism as GBA. Including the results of cross-sectional analysis, the associations of age at onset with rs34311866 (TMEM175, p.M393T), rs199347 (intron of GPNMB), and rs11060180 (intron of CCDC62) were found. TMEM175 has been reported to impair lysosomal and mitochondrial function and increase $\alpha$-synuclein aggregation, ${ }^{32}$ although no functional data for this missense variant were studied. Of interest, the variant has recently been reported in another study as being associated with the age at onset. ${ }^{33}$ rs 199347 is an eQTL increasing the 
brain expression of GPNMB, ${ }^{34}$ suggesting a causal link. Regarding rs1160180, no functional data are available in this locus.

We also evaluated the association between genetic risk variants and clinical outcomes by 2-step meta-analysis. This analysis is exploratory, and we acknowledge that this is biased toward the null due to power issues when partitioning studies randomly. However, we believe that it is helpful to assess the rigorousness of the associations we found in the primary analysis and to explore potential missed associations.

A strength of the current study was its design, incorporating multiple distinct independent Parkinson disease cohorts with longitudinal follow-ups. Although the cohorts contained patients at different disease stages, and some of the definition of outcomes were not identical, we analyzed each cohort separately and combined the results. Thus, the significant findings are consistent and applicable to the wider Parkinson disease populations. The forest plots showed that most of the estimates agree with each other despite the relative differences in the cohort characteristics. Another strength is the size of the study. The total number of genotyped and phenotyped patients with Parkinson disease $(N=4,307)$ is one of the largest to date for an investigation of disease progression.

The limitations of our study were as follows. First, we only included patients of European ancestry. It is uncertain whether the associations in the current study are also applicable to people from different ethnic backgrounds and further research is needed. Second, the current analysis could not distinguish causality, only basic associations. Different approaches, such as molecular-level assessment and Mendelian randomization, are crucial. Third, interaction effects between genes and other factors are another important research target not addressed in this report because of power constraints. For example, gene-bysmoking interactions for Parkinson disease were indicated recently $^{35}$ and highlight the importance of correctly modeling gene-environment interactions. Finally, compared with the typical GWAS analysis (which includes tens of thousands of cases), the number of participants was small, and the outcomes of interest were not as simple or easily defined as with case-control distinctions in GWAS. Acknowledging the limitations, the list of associations provided here is valuable as a foundation for further studies and as an example that illustrates the potential of efforts to define the genetic basis of variability in presentation and course. Accounting for this variability, even in part, has the potential to positively affect etiology-based clinical trials by reducing variability between placebo and treatment groups and by providing better predictions of expected individual progression.

\section{Acknowledgment}

The authors thank all study participants and their family, investigators, and members of the following studies: Parkinson Study Group: Deprenyl and Tocopherol Antioxidative Therapy of Parkinsonism (DATATOP); Drug Interaction with Genes in Parkinson's Disease (DIGPD); Harvard Biomarkers Study (HBS); NET-PD_LS1, NIH Exploratory
Trials in Parkinson's Disease Large Simple Study 1; Oslo PD study; ParkFit study; The Norwegian ParkWest study (ParkWest); Parkinson's Disease Biomarker Program (PDBP); Parkinsonism: Incidence and Cognitive and Non-motor heterogeneity In CambridgeShire (PICNICS); Parkinson's progression markers initiative (PPMI); Parkinson Study Group: Parkinson Research Examination of CEP-1347 Trial (PreCEPT) and its following study (PostCEPT); Profiling Parkinson's disease study (ProPark); and Morris K. Udall Centers for Parkinson's Research (Udall). They also thank the following grants and financial supporters of above studies; DATATOP was supported by a Public Health Service grant (NS24778) from the NINDS; by grants from the General Clinical Research Centers Program of the NIH at Columbia University (RR00645), the University of Virginia (RR00847), the University of Pennsylvania (RR00040), the University of Iowa (RR00059), Ohio State University (RR00034), Massachusetts General Hospital (RR01066), the University of Rochester (RR00044), Brown University (RR02038), Oregon Health Sciences University (RR00334), Baylor College of Medicine (RR00350), the University of California (RR00827), Johns Hopkins University (RR00035), the University of Michigan (RR00042), and Washington University (RR00036), the Parkinson's Disease Foundation at Columbia-Presbyterian Medical Center, the National Parkinson Foundation, the Parkinson Foundation of Canada, the United Parkinson Foundation, Chicago, the American Parkinson's Disease Association, New York, and the University of Rochester; DIGPD is supported by Assistance Publique Hôpitaux de Paris, funded by a grant from the French Ministry of Health (PHRC 2008, AOM08010) and a grant from the Agence Nationale pour la Sécurité des Médicaments (ANSM 2013); HBS is supported by the Harvard NeuroDiscovery Center, Michael J Fox Foundation, NINDS U01NS082157, U01NS100603, and the Massachusetts Alzheimer's Disease Research Center NIA P50AG005134; NET-PD_LS1 was supported by NINDS grants U01NS043128; OSLO is supported by the Research Council of Norway and SouthEastern Norway Regional Health Authority; ParkFit is supported by ZonMw (the Netherlands Organization for Health Research and Development [75020012]) and the Michael J Fox Foundation for Parkinson's research, VGZ (health insurance company), GlaxoSmithKline, and the National Parkinson Foundation; ParkWest is supported by the Research Council of Norway, the Western Norway Regional Health Authority, Stavanger University Hospital Research Funds, and the Norwegian Parkinson's Disease Association; PDBP is a consortium with NINDS initiative; PICNICS has received funding from the Cure Parkinson's Trust, the Van Geest Foundation and is supported by the NIH Research Cambridge Biomedical Research Centre; PPMI is supported by the Michael J Fox Foundation for Parkinson's research; PreCEPT and PostCEPT were funded by NINDS 5U01NS050095-05, Department of Defense Neurotoxin Exposure Treatment Parkinson's Research Program (Grant Number: W23RRYX7022N606), the Michael J Fox Foundation for Parkinson's Research, Parkinson's Disease Foundation, 
Lundbeck Pharmaceuticals. Cephalon Inc, Lundbeck Inc, John Blume Foundation, Smart Family Foundation, RJG Foundation, Kinetics Foundation, National Parkinson Foundation, Amarin Neuroscience LTD, CHDI Foundation Inc, NIH (NHGRI and NINDS), and Columbia Parkinson's Disease Research Center; ProPARK is funded by the Alkemade-Keuls Foundation, Stichting Parkinson Fonds, Parkinson Vereniging, and The Netherlands Organization for Health Research and Development; Udall is supported by the NINDS.

\section{Study funding}

This study is supported by the Intramural Research Program, the National Institute on Aging (NIA, Z01-AG000949-02), Biogen Idec, and the Michael J Fox Foundation for Parkinson's Research. The funders of the study had no role in study design, data collection, data analysis, data interpretation, or writing of the report. The authors had full access to the data in the study and had final responsibility for the decision to submit for publication.

\section{Disclosure}

H. Iwaki-grants: Michael J Fox Foundation. J. MapleGrødem-grants: Norwegian Parkinson's Disease Association. J.-C. Corvol-advisory boards: Biogen, Air Liquide, BrainEver, Theranexus, BMS, Zambon, Pfizer, Ipsen, and AbbVie; grants: MJFF, Actelion, and Ipsen. L. Pihlstrømgrants: Norwegian Health Association, South-East Norway Regional Health Authority, Norwegian Parkinson Research Fund, and Michael J. Fox Foundation. K.-D.H. Nguyenstock ownership in medically related fields: Biotech/ Pharmaceutical Industry. K.M. Scott-grants: Wellcome Trust PhD Fellowship. V.M. Van Deerlin-grants: NIH NS053488. A.G. Day-Williams_-stock ownership in medically related fields: Biogen and Merck. A. Brice-advisory boards: FWO and ERC; grants: JPND, ANR, Eranet Neuron, and Association France Parkinson. A.J. Noyce-honoraria: Britannia Pharmaceuticals; grants: Parkinson's UK (G-1606). J.R. Evans-advisory boards: AbbVie, Global Kinetics, and Allergan; honoraria: UCB, Allergan, and AbbVie. K. Estrada - stock ownership in medically related fields: Biogen. D.K. Simon-consultancies: Lysosomal Therapeutics, Inc.; advisory boards: Weston Brain Institute; honoraria: Parkinson Study Group, Harvard Medical School, Michael J Fox Foundation, and Biogen; grants: NIH, Weston Brain Institute, Mission Therapeutics, Inc., and BioElectron Technologies. B. Ravina-stock ownership in medically related fields: Voyager Therapeutics; consultancies: Michael J Fox Foundation. M. Toft-honoraria: Roche; grants: Research Council of Norway, South-Eastern Norway Regional Health Authority, and Michael J. Fox Foundation. B.R. Bloemconsultancies: AbbVie and Zambon; advisory boards: Michael J Fox Foundation; honoraria and speaker fees: AbbVie, Zambon, and Bial; grants: The Netherlands Organization for Scientific Research, the Michael J Fox Foundation, UCB, AbbVie, the Stichting Parkinson Fonds, the Hersenstichting Nederland, the Parkinson's Foundation, Verily Life Sciences, the Topsector Life Sciences and Health, and the Parkinson
Vereniging. D. Weintraub_consultancies: Acadia, Alkahest, Anavex Life Sciences, BlackThorn Therapeutics, Bracket, Clintrex LLC, Sunovion, Theravance Biopharma, and the CHDI Foundation. R.A. Barker-consultancies: CDI and Oxford Biomedica; royalties: Springer and Wiley; grants: EU, NIHR, PUK, CPT, Rosetrees Trust, MRC, Wellcome Trust, and Evelyn Trust. C.H. Williams-Gray-grants: MRC Clinician Scientist fellowship, the NIHR Cambridge Biomedical Research Centre, the Michael J Fox Foundation, the Rosetrees Trust, the Evelyn Trust, and Addenbrookes Charitable Trust. B.P. van de Warrenburg - advisory boards: member of medical advisory boards and patient organizations; royalties: Reed Elsevier (for chapter in Dutch Neurology textbook); grants: Radboud University Medical Centre, ZonMW, Hersenstichting, and Bioblast Pharma. J.J. Van Hilten-grants: Alkemade-Keuls Foundation, Stichting Parkinson Fonds, Parkinson Vereniging, and The Netherlands Organisation for Health Research and Development. C.R. Scherzer-grants: NIH grants U01NS082157, U01NS095736, and U01NS100603. M.A. Nalls-consultancies: Lysosomal Therapies Inc., Vivid Genomics Inc., Kleiner Perkins Caufield \& Byers, and Michael J. Fox Foundation. Go to Neurology.org/NG for full disclosures.

\section{Publication history}

Received by Neurology: Genetics November 13, 2018. Accepted in final form April 30, 2019.

\begin{tabular}{|c|c|c|c|}
\hline Name & Location & Role & Contributions \\
\hline $\begin{array}{l}\text { Hirotaka Iwaki, } \\
\text { MD, PhD }\end{array}$ & $\begin{array}{l}\text { Laboratory of } \\
\text { Neurogenetics, } \\
\text { National Institute on } \\
\text { Aging, National } \\
\text { Institutes of Health, } \\
\text { Bethesda, MD }\end{array}$ & Author & $\begin{array}{l}\text { Literature search; } \\
\text { study design; data } \\
\text { analysis; data } \\
\text { interpretation; and } \\
\text { writings }\end{array}$ \\
\hline $\begin{array}{l}\text { Cornelis } \\
\text { Blauwendraat, } \\
\text { PhD }\end{array}$ & $\begin{array}{l}\text { Laboratory of } \\
\text { Neurogenetics, } \\
\text { National Institute on } \\
\text { Aging, National } \\
\text { Institutes of Health, } \\
\text { Bethesda, MD }\end{array}$ & Author & $\begin{array}{l}\text { Literature search; } \\
\text { data analysis; data } \\
\text { interpretation; and } \\
\text { critical review }\end{array}$ \\
\hline $\begin{array}{l}\text { Hampton L. } \\
\text { Leonard, MS }\end{array}$ & $\begin{array}{l}\text { Laboratory of } \\
\text { Neurogenetics, } \\
\text { National Institute on } \\
\text { Aging, National } \\
\text { Institutes of Health, } \\
\text { Bethesda, MD }\end{array}$ & Author & Critical review \\
\hline $\begin{array}{l}\text { Ganqiang Liu, } \\
\text { PhD }\end{array}$ & $\begin{array}{l}\text { Precision Neurology } \\
\text { Program, Harvard } \\
\text { Medical School, } \\
\text { Brigham and } \\
\text { Women's Hospital, } \\
\text { Boston, MA }\end{array}$ & Author & $\begin{array}{l}\text { Data collection and } \\
\text { critical review }\end{array}$ \\
\hline $\begin{array}{l}\text { Jodi Maple- } \\
\text { Grødem, PhD }\end{array}$ & $\begin{array}{l}\text { The Norwegian } \\
\text { Centre for Movement } \\
\text { Disorders, Stavanger } \\
\text { University Hospital, } \\
\text { Stavanger, Norway }\end{array}$ & Author & $\begin{array}{l}\text { Data collection and } \\
\text { critical review }\end{array}$ \\
\hline
\end{tabular}


Appendix (continued)

\begin{tabular}{|c|c|c|c|}
\hline Name & Location & Role & Contributions \\
\hline $\begin{array}{l}\text { Jean- } \\
\text { Christophe } \\
\text { Corvol, MD, } \\
\text { PhD }\end{array}$ & $\begin{array}{l}\text { Assistance-Publique } \\
\text { Hôpitaux de Paris, } \\
\text { ICM, INSERM UMRS } \\
\text { 1127, CNRS 7225, } \\
\text { ICM, Department of } \\
\text { Neurology and CIC } \\
\text { Neurosciences, Pitié- } \\
\text { Salpêtrière Hospital, } \\
\text { Paris, France }\end{array}$ & Author & $\begin{array}{l}\text { Data collection and } \\
\text { critical review }\end{array}$ \\
\hline $\begin{array}{l}\text { Lasse } \\
\text { Pihlstrøm, MD, } \\
\text { PhD }\end{array}$ & $\begin{array}{l}\text { Department of } \\
\text { Neurology, Oslo } \\
\text { University Hospital, } \\
\text { Oslo, Norway }\end{array}$ & Author & $\begin{array}{l}\text { Data collection and } \\
\text { critical review }\end{array}$ \\
\hline $\begin{array}{l}\text { Marlies van } \\
\text { Nimwegen, } \\
\text { PhD }\end{array}$ & $\begin{array}{l}\text { Department of } \\
\text { Neurology, Donders } \\
\text { Institute for Brain, } \\
\text { Cognition, and } \\
\text { Behaviour, Radboud } \\
\text { University Medical } \\
\text { Centre, Nijmegen, } \\
\text { The Netherlands }\end{array}$ & Author & $\begin{array}{l}\text { Data collection and } \\
\text { critical review }\end{array}$ \\
\hline $\begin{array}{l}\text { Samantha J. } \\
\text { Hutten, PhD }\end{array}$ & $\begin{array}{l}\text { Michael J Fox } \\
\text { Foundation, New } \\
\text { York, NY }\end{array}$ & Author & $\begin{array}{l}\text { Data collection and } \\
\text { critical review }\end{array}$ \\
\hline $\begin{array}{l}\text { Khanh-Dung H. } \\
\text { Nguyen, PhD }\end{array}$ & $\begin{array}{l}\text { Translational } \\
\text { Genome Sciences, } \\
\text { Biogen, Cambridge, } \\
\text { MA }\end{array}$ & Author & $\begin{array}{l}\text { Data collection and } \\
\text { critical review }\end{array}$ \\
\hline $\begin{array}{l}\text { Jacqueline } \\
\text { Rick, PhD }\end{array}$ & $\begin{array}{l}\text { Department of } \\
\text { Neurology University } \\
\text { of Pennsylvania, } \\
\text { Philadelphia, PA }\end{array}$ & Author & $\begin{array}{l}\text { Data collection and } \\
\text { critical review }\end{array}$ \\
\hline $\begin{array}{l}\text { Shirley Eberly, } \\
\text { MS }\end{array}$ & $\begin{array}{l}\text { Department of } \\
\text { Biostatistics and } \\
\text { Computational } \\
\text { Biology, University of } \\
\text { Rochester, Rochester, } \\
\text { NY }\end{array}$ & Author & $\begin{array}{l}\text { Data collection and } \\
\text { critical review }\end{array}$ \\
\hline $\begin{array}{l}\text { Faraz Faghri, } \\
\text { MS }\end{array}$ & $\begin{array}{l}\text { Laboratory of } \\
\text { Neurogenetics, } \\
\text { National Institute on } \\
\text { Aging, National } \\
\text { Institutes of Health, } \\
\text { Bethesda, MD }\end{array}$ & Author & $\begin{array}{l}\text { Data collection and } \\
\text { critical review }\end{array}$ \\
\hline $\begin{array}{l}\text { Peggy Auinger, } \\
\text { MS }\end{array}$ & $\begin{array}{l}\text { Department of } \\
\text { Neurology, Center for } \\
\text { Health + Technology, } \\
\text { University of } \\
\text { Rochester, Rochester, } \\
\text { NY }\end{array}$ & Author & $\begin{array}{l}\text { Data collection and } \\
\text { critical review }\end{array}$ \\
\hline $\begin{array}{l}\text { Kirsten M. } \\
\text { Scott, MRCP, } \\
\text { MPhil }\end{array}$ & $\begin{array}{l}\text { Department of } \\
\text { Clinical } \\
\text { Neurosciences, } \\
\text { University of } \\
\text { Cambridge, John van } \\
\text { Geest Centre for } \\
\text { Brain Repair, } \\
\text { Cambridge, UK }\end{array}$ & Author & $\begin{array}{l}\text { Data collection and } \\
\text { critical review }\end{array}$ \\
\hline $\begin{array}{l}\text { Ruwani } \\
\text { Wijeyekoon, } \\
\text { MRCP }\end{array}$ & $\begin{array}{l}\text { Department of } \\
\text { Clinical } \\
\text { Neurosciences, } \\
\text { University of } \\
\text { Cambridge, John van } \\
\text { Geest Centre for } \\
\text { Brain Repair, } \\
\text { Cambridge, UK }\end{array}$ & Author & $\begin{array}{l}\text { Data collection and } \\
\text { critical review }\end{array}$ \\
\hline
\end{tabular}

Appendix (continued)

\begin{tabular}{|c|c|c|c|}
\hline Name & Location & Role & Contributions \\
\hline $\begin{array}{l}\text { Vivianna M. } \\
\text { Van Deerlin, } \\
\text { MD, PhD }\end{array}$ & $\begin{array}{l}\text { Department of } \\
\text { Pathology and } \\
\text { Laboratory Medicine, } \\
\text { Center for } \\
\text { Neurodegenerative } \\
\text { Disease Research, } \\
\text { Parelman School of } \\
\text { Medicine at the } \\
\text { University of } \\
\text { Pennsylvania, } \\
\text { Philadelphia, PA }\end{array}$ & Author & $\begin{array}{l}\text { Data collection and } \\
\text { critical review }\end{array}$ \\
\hline $\begin{array}{l}\text { Dena G. } \\
\text { Hernandez, } \\
\text { PhD }\end{array}$ & $\begin{array}{l}\text { Laboratory of } \\
\text { Neurogenetics, } \\
\text { National Institute on } \\
\text { Aging, National } \\
\text { Institutes of Health, } \\
\text { Bethesda, MD }\end{array}$ & Author & $\begin{array}{l}\text { Data collection and } \\
\text { critical review }\end{array}$ \\
\hline $\begin{array}{l}\text { Aaron G. Day- } \\
\text { Williams, PhD }\end{array}$ & $\begin{array}{l}\text { Genetics and } \\
\text { Pharmacogenomics, } \\
\text { Merck Research } \\
\text { Laboratory, Boston, } \\
\text { MA }\end{array}$ & Author & $\begin{array}{l}\text { Data collection and } \\
\text { critical review }\end{array}$ \\
\hline $\begin{array}{l}\text { Alexis Brice, } \\
\text { MD }\end{array}$ & $\begin{array}{l}\text { Institut du cerveau et } \\
\text { de la moelle épinière } \\
\text { ICM, Paris, France }\end{array}$ & Author & $\begin{array}{l}\text { Data collection and } \\
\text { critical review }\end{array}$ \\
\hline $\begin{array}{l}\text { Guido Alves, } \\
\text { MD, PhD }\end{array}$ & $\begin{array}{l}\text { The Norwegian } \\
\text { Centre for Movement } \\
\text { Disorders, Stavanger } \\
\text { University Hospital, } \\
\text { Stavanger, Norway }\end{array}$ & Author & $\begin{array}{l}\text { Data collection and } \\
\text { critical review }\end{array}$ \\
\hline $\begin{array}{l}\text { Alastair J. } \\
\text { Noyce, MRCP, } \\
\text { PhD }\end{array}$ & $\begin{array}{l}\text { Preventive Neurology } \\
\text { Unit, Wolfson } \\
\text { Institute of } \\
\text { Preventive Medicine, } \\
\text { Queen Mary } \\
\text { University of London, } \\
\text { London, UK }\end{array}$ & Author & $\begin{array}{l}\text { Data collection and } \\
\text { critical review }\end{array}$ \\
\hline $\begin{array}{l}\text { Ole-Bjørn } \\
\text { Tysnes, MD, } \\
\text { PhD }\end{array}$ & $\begin{array}{l}\text { Department of } \\
\text { Neurology, } \\
\text { Haukeland University } \\
\text { Hospital, Bergen, } \\
\text { Norway }\end{array}$ & Author & $\begin{array}{l}\text { Data collection and } \\
\text { critical review }\end{array}$ \\
\hline $\begin{array}{l}\text { Jonathan R. } \\
\text { Evans, MRCP, } \\
\text { PhD }\end{array}$ & $\begin{array}{l}\text { Department of } \\
\text { Neurology, } \\
\text { Nottingham } \\
\text { University NHS Trust, } \\
\text { Nottingham, UK }\end{array}$ & Author & $\begin{array}{l}\text { Data collection and } \\
\text { critical review }\end{array}$ \\
\hline $\begin{array}{l}\text { David P. Breen, } \\
\text { MRCP, PhD }\end{array}$ & $\begin{array}{l}\text { Centre for Clinical } \\
\text { Brain Sciences, } \\
\text { University of } \\
\text { Edinburgh, } \\
\text { Edinburgh, Scotland }\end{array}$ & Author & $\begin{array}{l}\text { Data collection and } \\
\text { critical review }\end{array}$ \\
\hline $\begin{array}{l}\text { Karol Estrada, } \\
\text { PhD }\end{array}$ & $\begin{array}{l}\text { Translational } \\
\text { Genome Sciences, } \\
\text { Biogen, Cambridge, } \\
\text { MA }\end{array}$ & Author & $\begin{array}{l}\text { Data collection and } \\
\text { critical review }\end{array}$ \\
\hline $\begin{array}{l}\text { Claire E. Wegel, } \\
\text { MPH }\end{array}$ & $\begin{array}{l}\text { Department of } \\
\text { Medical and } \\
\text { Molecular Genetics, } \\
\text { Indiana University, } \\
\text { Indianapolis, IN }\end{array}$ & Author & $\begin{array}{l}\text { Data collection and } \\
\text { critical review }\end{array}$ \\
\hline $\begin{array}{l}\text { Fabrice } \\
\text { Danjou, MD, } \\
\text { PhD }\end{array}$ & $\begin{array}{l}\text { Institut du cerveau } \\
\text { et de la moelle } \\
\text { épinière ICM, Paris, } \\
\text { France }\end{array}$ & Author & $\begin{array}{l}\text { Data collection and } \\
\text { critical review }\end{array}$ \\
\hline
\end{tabular}


Appendix (continued)

\begin{tabular}{|c|c|c|c|}
\hline Name & Location & Role & Contributions \\
\hline $\begin{array}{l}\text { David K. Simon, } \\
\text { MD, PhD }\end{array}$ & $\begin{array}{l}\text { Department of } \\
\text { Neurology, Beth } \\
\text { Israel Deaconess } \\
\text { Medical Center, } \\
\text { Boston, MA }\end{array}$ & Author & $\begin{array}{l}\text { Data collection and } \\
\text { critical review }\end{array}$ \\
\hline $\begin{array}{l}\text { Bernard } \\
\text { Ravina, MD }\end{array}$ & $\begin{array}{l}\text { Voyager } \\
\text { Therapeutics, } \\
\text { Cambridge, } \\
\text { MA }\end{array}$ & Author & $\begin{array}{l}\text { Data collection and } \\
\text { critical review }\end{array}$ \\
\hline $\begin{array}{l}\text { Mathias Toft, } \\
\text { MD, PhD }\end{array}$ & $\begin{array}{l}\text { Department of } \\
\text { Neurology, Oslo } \\
\text { University Hospital, } \\
\text { Oslo, Norway }\end{array}$ & Author & $\begin{array}{l}\text { Data collection and } \\
\text { critical review }\end{array}$ \\
\hline $\begin{array}{l}\text { Peter Heutink, } \\
\text { PhD }\end{array}$ & $\begin{array}{l}\text { German Center for } \\
\text { Neurodegenerative } \\
\text { Diseases-Tubingen, } \\
\text { Tuebingen, Germany }\end{array}$ & Author & $\begin{array}{l}\text { Data collection and } \\
\text { critical review }\end{array}$ \\
\hline $\begin{array}{l}\text { Bastiaan R. } \\
\text { Bloem, MD, } \\
\text { PhD }\end{array}$ & $\begin{array}{l}\text { Department of } \\
\text { Neurology, Donders } \\
\text { Institute for Brain, } \\
\text { Cognition, and } \\
\text { Behaviour, Radboud } \\
\text { University Medical } \\
\text { Centre, Nijmegen, } \\
\text { The Netherlands }\end{array}$ & Author & $\begin{array}{l}\text { Data collection and } \\
\text { critical review }\end{array}$ \\
\hline $\begin{array}{l}\text { Daniel } \\
\text { Weintraub, MD }\end{array}$ & $\begin{array}{l}\text { Department of } \\
\text { Psychiatry, University } \\
\text { of Pennsylvania } \\
\text { School of Medicine, } \\
\text { Philadelphia, } \\
\text { PA }\end{array}$ & Author & $\begin{array}{l}\text { Data collection and } \\
\text { critical review }\end{array}$ \\
\hline $\begin{array}{l}\text { Roger A. } \\
\text { Barker, MRCP, } \\
\text { PhD }\end{array}$ & $\begin{array}{l}\text { Department of } \\
\text { Clinical } \\
\text { Neurosciences, } \\
\text { University of } \\
\text { Cambridge, } \\
\text { Cambridge, } \\
\text { UK }\end{array}$ & Author & $\begin{array}{l}\text { Data collection and } \\
\text { critical review }\end{array}$ \\
\hline $\begin{array}{l}\text { Caroline H. } \\
\text { Williams-Gray, } \\
\text { MRCP, PhD }\end{array}$ & $\begin{array}{l}\text { Department of } \\
\text { Clinical } \\
\text { Neurosciences, } \\
\text { University of } \\
\text { Cambridge, } \\
\text { Cambridge, } \\
\text { UK }\end{array}$ & Author & $\begin{array}{l}\text { Data collection and } \\
\text { critical review }\end{array}$ \\
\hline $\begin{array}{l}\text { Bart P. van de } \\
\text { Warrenburg, } \\
\text { MD, PhD }\end{array}$ & $\begin{array}{l}\text { Department of } \\
\text { Neurology, Donders } \\
\text { Institute for Brain, } \\
\text { Cognition, and } \\
\text { Behaviour, Radboud } \\
\text { University Medical } \\
\text { Centre, Nijmegen, } \\
\text { The Netherlands }\end{array}$ & Author & $\begin{array}{l}\text { Data collection and } \\
\text { critical review }\end{array}$ \\
\hline $\begin{array}{l}\text { Jacobus J. Van } \\
\text { Hilten, MD, } \\
\text { PhD }\end{array}$ & $\begin{array}{l}\text { Department of } \\
\text { Neurology, Leiden } \\
\text { University Medical } \\
\text { Center, Leiden, The } \\
\text { Netherlands }\end{array}$ & Author & $\begin{array}{l}\text { Data collection and } \\
\text { critical review }\end{array}$ \\
\hline $\begin{array}{l}\text { Clemens R. } \\
\text { Scherzer, MD }\end{array}$ & $\begin{array}{l}\text { Precision Neurology } \\
\text { Program, Harvard } \\
\text { Medical School, } \\
\text { Brigham and } \\
\text { Women's Hospital, } \\
\text { Boston, } \\
\text { MA }\end{array}$ & Author & $\begin{array}{l}\text { Data collection and } \\
\text { critical review }\end{array}$ \\
\hline
\end{tabular}

Appendix (continued)

\begin{tabular}{|c|c|c|c|}
\hline Name & Location & Role & Contributions \\
\hline $\begin{array}{l}\text { Andrew B. } \\
\text { Singleton, PhD }\end{array}$ & $\begin{array}{l}\text { Laboratory of } \\
\text { Neurogenetics, } \\
\text { National Institute on } \\
\text { Aging, National } \\
\text { Institutes of Health, } \\
\text { Bethesda, MD }\end{array}$ & Author & $\begin{array}{l}\text { Study design and } \\
\text { critical review }\end{array}$ \\
\hline $\begin{array}{l}\text { Mike A. Nalls, } \\
\text { PhD }\end{array}$ & $\begin{array}{l}\text { Laboratory of } \\
\text { Neurogenetics, } \\
\text { National Institute on } \\
\text { Aging, National } \\
\text { Institutes of Health, } \\
\text { Bethesda, MD }\end{array}$ & Author & $\begin{array}{l}\text { Study design; data } \\
\text { analysis; data } \\
\text { interpretation; and } \\
\text { critical review }\end{array}$ \\
\hline
\end{tabular}

\section{References}

1. Elbaz A, Bower JH, Maraganore DM, et al. Risk tables for parkinsonism and Parkinson's disease. J Clin Epidemiol 2002;55:25-31.

2. Chaudhuri KR, Healy DG, Schapira AHV; National Institute for Clinical Excellence. Non-motor symptoms of Parkinson's disease: diagnosis and management. Lancet Neurol 2006;5:235-245.

3. Lewis SJG, Foltynie T, Blackwell AD, Robbins TW, Owen AM, Barker RA. Heterogeneity of Parkinson's disease in the early clinical stages using a data driven approach. J Neurol Neurosurg Psychiatry 2005;76:343-348.

4. Satake W, Nakabayashi Y, Mizuta I, et al. Genome-wide association study identifies common variants at four loci as genetic risk factors for Parkinson's disease. Nat Genet 2009;41:1303-1307.

5. Simón-Sánchez J, Schulte C, Bras JM, et al. Genome-wide association study reveals genetic risk underlying Parkinson's disease. Nat Genet 2009;41:1308-1312.

6. Chang D, Nalls MA, Hallgrímsdóttir IB, et al. A meta-analysis of genome-wide association studies identifies 17 new Parkinson's disease risk loci. Nat Genet 2017;49: 1511-1516.

7. International Parkinson Disease Genomics Consortium, Nalls MA, Plagnol V, Hernandez DG, et al. Imputation of sequence variants for identification of genetic risks for Parkinson's disease: a meta-analysis of genome-wide association studies. Lancet 2011; 377:641-649.

8. Nalls MA, Bras J, Hernandez DG, et al. NeuroX, a fast and efficient genotyping platform for investigation of neurodegenerative diseases. Neurobiol Aging 2015;36: 1605.e7-1605.e12.

9. Nalls MA, Escott-Price V, Williams NM, et al. Genetic risk and age in Parkinson's disease: continuum not stratum. Mov Disord 2015;30:850-854.

10. Nalls MA, McLean CY, Rick J, et al. Diagnosis of Parkinson's disease on the basis of clinical and genetic classification: a population-based modelling study. Lancet Neurol 2015;14:1002-1009.

11. Pankratz N, Beecham GW, DeStefano AL, et al. Meta-analysis of Parkinson's disease: identification of a novel locus, RIT2. Ann Neurol 2012;71:370-384.

12. Davis AA, Andruska KM, Benitez BA, Racette BA, Perlmutter JS, Cruchaga C. Variants in GBA, SNCA, and MAPT influence Parkinson disease risk, age at onset, and progression. Neurobiol Aging 2016;37:209.e1-209.e7.

13. Picillo M, Pellecchia MT, Erro R, et al. The use of university of Pennsylvania Smell identification test in the diagnosis of Parkinson's disease in Italy. Neurol Sci 2014;35:379-383.

14. Hoops S, Nazem S, Siderowf AD, et al. Validity of the MoCA and MMSE in the detection of MCI and dementia in Parkinson disease. Neurology 2009;73: 1738-1745.

15. Verbaan D, van Rooden SM, van Hilten JJ, Rijsman RM. Prevalence and clinical profile of restless legs syndrome in Parkinson's disease. Mov Disord 2010;25: 2142-2147.

16. Goodarzi Z, Mrklas KJ, Roberts DJ, Jette N, Pringsheim T, Holroyd-Leduc J. Detecting depression in Parkinson disease: a systematic review and meta-analysis. Neurology 2016;87:426-437.

17. Simuni T, Caspell-Garcia C, Coffey C, et al. Correlates of excessive daytime sleepiness in de novo Parkinson's disease: a case control study. Mov Disord 2015;30:1371-1381.

18. Boeve BF, Molano JR, Ferman TJ, et al. Validation of the Mayo sleep questionnaire to screen for REM sleep behavior disorder in an aging and dementia cohort. Sleep Med $2011 ; 12: 445-453$.

19. Nomura T, Inoue Y, Kagimura T, Uemura Y, Nakashima K. Utility of the REM sleep behavior disorder screening questionnaire (RBDSQ) in Parkinson's disease patients. Sleep Med 2011;12:711-713.

20. Boeve BF, Molano JR, Ferman TJ, et al. Validation of the Mayo sleep questionnaire to screen for REM sleep behavior disorder in a community-based sample. J Clin Sleep Med 2013;9:475-480.

21. Davis MY, Johnson CO, Leverenz JB, et al. Association of GBA mutations and the E326K polymorphism with motor and cognitive progression in Parkinson disease. JAMA Neurol 2016;73:1217-1224. 
22. Winder-Rhodes SE, Evans JR, Ban M, et al. Glucocerebrosidase mutations influence the natural history of Parkinson's disease in a community-based incident cohort. Brain 2013;136:392-399.

23. Brockmann K, Srulijes K, Pflederer S, et al. GBA-associated Parkinson's disease: reduced survival and more rapid progression in a prospective longitudinal study. Mov Disord 2015;30:407-411.

24. Liu G, Boot B, Locascio JJ, et al. Specifically neuropathic Gaucher's mutations accelerate cognitive decline in Parkinson's. Ann Neurol 2016;80:674-685.

25. Liu G, Locascio JJ, Corvol JC, et al. Prediction of cognition in Parkinson's disease with a clinical-genetic score: a longitudinal analysis of nine cohorts. Lancet Neurol 2017; 16:620-629.

26. Gan-Or Z, Mirelman A, Postuma RB, et al. GBA mutations are associated with rapid eye movement sleep behavior disorder. Ann Clin Transl Neurol 2015;2:941-945.

27. Brockmann K, Srulijes K, Hauser AK, et al. GBA-associated PD presents with nonmotor characteristics. Neurology 2011;77:276-280.

28. Oeda T, Umemura A, Mori Y, et al. Impact of glucocerebrosidase mutations on motor and nonmotor complications in Parkinson's disease. Neurobiol Aging 2015;36: 3306-3313.
29. Jesús S, Huertas I, Bernal-Bernal I, et al. GBA variants influence motor and non-motor features of Parkinson's disease. PLoS One 2016;11:e0167749.

30. Marras C, Alcalay RN, Caspell-Garcia C, et al. Motor and nonmotor heterogeneity of LRRK2-related and idiopathic Parkinson's disease. Mov Disord 2016; 31:1192-1202.

31. Võsa U, Claringbould P, Westra HJ, et al. Unraveling the polygenic architecture of complex traits using blood eQTL meta-analysis. bioRxiv Epub 2018 Oct 19.

32. Jinn S, Drolet RE, Cramer PE, et al. TMEM175 deficiency impairs lysosomal and mitochondrial function and increases $\alpha$-synuclein aggregation. Proc Natl Acad Sci U S A $2017 ; 114: 2389-2394$.

33. Blauwendraat C, Heilbron K, Vallerga CL, Bandres-Ciga S, Coelln Rvon, Pihlstrøm L. Parkinson disease age at onset GWAS: defining heritability, genetic loci and $\alpha$-synuclein mechanisms. Mov Disord Epub 2019 Apr 7.

34. UKBEC; Murthy MN, Blauwendraat C, Guelfi S, et al. Increased brain expression of GPNMB is associated with genome wide significant risk for Parkinson's disease on chromosome 7p15.3. Neurogenetics 2017;18:121-133.

35. Lee PC, Ahmed I, Loriot MA, et al. Smoking and Parkinson disease: evidence for gene-by-smoking interactions. Neurology 2018;90:e583-e592. 


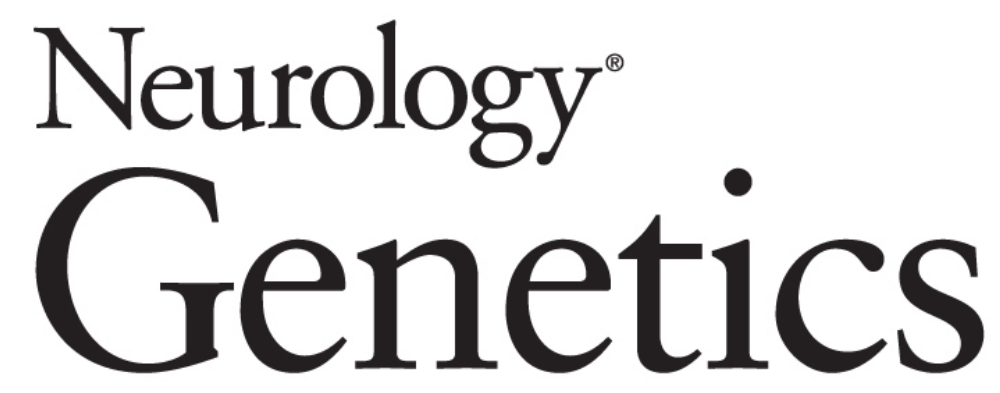

Genetic risk of Parkinson disease and progression:: An analysis of 13 longitudinal cohorts

Hirotaka Iwaki, Cornelis Blauwendraat, Hampton L. Leonard, et al.

Neurol Genet 2019;5;

DOI 10.1212/NXG.0000000000000348

This information is current as of July 9, 2019

Neurol Genet is an official journal of the American Academy of Neurology. Published since April 2015, it is an open-access, online-only, continuous publication journal. Copyright Copyright ( 2019 The Author(s).

Published by Wolters Kluwer Health, Inc. on behalf of the American Academy of Neurology.. All rights reserved. Online ISSN: 2376-7839.

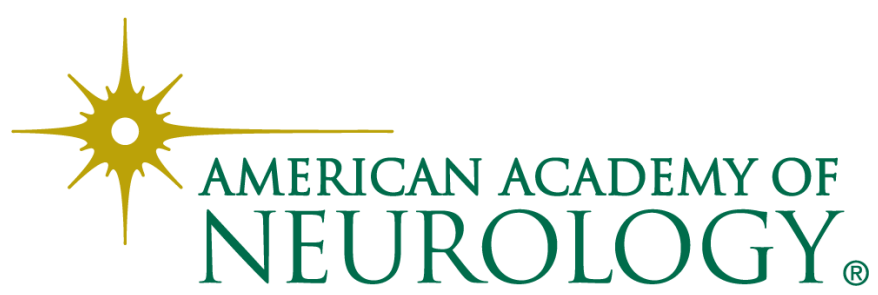




\section{Updated Information \& Services}

References

Citations

Subspecialty Collections

Errata

Permissions \& Licensing

Reprints including high resolution figures, can be found at: http://ng.neurology.org/content/5/4/e348.full.html

This article cites 33 articles, 2 of which you can access for free at: http://ng.neurology.org/content/5/4/e348.full.html\#\#ref-list-1

This article has been cited by 17 HighWire-hosted articles: http://ng.neurology.org/content/5/4/e348.full.html\#\#otherarticles

This article, along with others on similar topics, appears in the following collection(s):

Association studies in genetics

http://ng.neurology.org//cgi/collection/association_studies_in_genetics Cohort studies

http://ng.neurology.org//cgi/collection/cohort_studies

Parkinson's disease with dementia

http://ng.neurology.org//cgi/collection/parkinsons_disease_with_deme ntia

Parkinson's disease/Parkinsonism

http://ng.neurology.org//cgi/collection/parkinsons_disease_parkinsonis $\mathrm{m}$

Prognosis

http://ng.neurology.org//cgi/collection/prognosis

An erratum has been published regarding this article. Please see next page or:

/content/5/4/e354.full.pdf

Information about reproducing this article in parts (figures,tables) or in its entirety can be found online at:

http://ng.neurology.org/misc/about.xhtml\#permissions

Information about ordering reprints can be found online:

http://ng.neurology.org/misc/addir.xhtml\#reprintsus

Neurol Genet is an official journal of the American Academy of Neurology. Published since April 2015, it is an open-access, online-only, continuous publication journal. Copyright Copyright () 2019 The Author(s). Published by Wolters Kluwer Health, Inc. on behalf of the American Academy of Neurology.. All rights reserved. Online ISSN: 2376-7839.

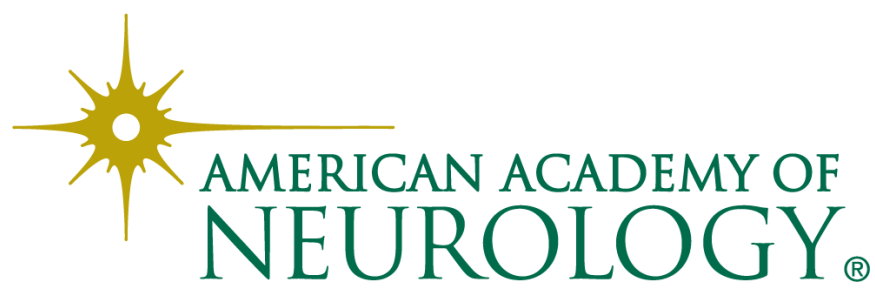




\section{CORRECTION}

\section{Genetic risk of Parkinson disease and progression: An analysis of 13}

longitudinal cohorts

Neurol Genet 2019;5:e354. doi:10.1212/NXG.0000000000000354

In the article "Genetic risk of Parkinson disease and progression: An analysis of 13 longitudinal cohorts" by Iwaki et al., ${ }^{1}$ first published online July 9, 2019, in the abstract's results, the phrase should be "T allele of rs114128760." The authors regret the error.

\section{Reference}

1. Iwaki H, Blauwendraat C, Leonard HL, et al. Genetic risk of Parkinson disease and progression: An analysis of 13 longitudinal cohorts. Neurol Genet 2019;5:e348. 